\title{
The linkages of plant, litter and soil C:N:P stoichiometry and nutrient stock in different secondary mixed forest types in the Qinling Mountains, China
}

\author{
Yue Pang ${ }^{1}$, Jing Tian ${ }^{1}$, Xuan Zhao ${ }^{1}$, Zhi Chao ${ }^{1}$, Yuchao Wang ${ }^{2,3}$, Xinping Zhang ${ }^{4}$, Dexiang Wang ${ }^{\text {Corresp. } 1}$ \\ ${ }^{1}$ College of Forestry, Northwest A\&F University, Yangling, China \\ 2 Institute of Botany of Shaanxi Province, Xi'an, China \\ 3 Shaanxi Engineering Research Centre for Conservation and Utilization of Botanical Resources, Xi'an, China \\ ${ }^{4}$ School of art and design, Xi'an university of technology, Xi'an, China \\ Corresponding Author: Dexiang Wang \\ Email address: wangdx66@sohu.com
}

Background. Carbon $(\mathrm{C})$, nitrogen $(\mathrm{N})$, and phosphorus $(\mathrm{P})$ stoichiometric ratios are important indicators of ecosystem function and productivity. However, few studies have assessed the nutrient relationship between plant, litter and soil, and the nutrient stock in different secondary mixed forest types.

Methods. We investigated the $\mathrm{C}, \mathrm{N}$, and $\mathrm{P}$ concentrations and stoichiometric ratios in trees, understory plants, litter, and soil layers in three different secondary mixed forest types (broadleaf mixed forests $(B M)$, broadleaf-conifer mixed forests (BCM) and coniferous mixed forests $(C M))$ in the Qinling Mountains.

Results. The results showed that significant differences in $\mathrm{C}: \mathrm{N}: \mathrm{P}$ stoichiometry were detected in multiple organs in the vegetation layers in the different forest types. Trees, shrubs and herbs all allocated more $\mathrm{N}$ and $P$ in leaves and had a higher $N: P$ ratio in leaves than in other organs. The $C$ concentrations, $C: N$ ratios and $\mathrm{C}: \mathrm{P}$ ratios of all tree organs showed a decreasing order: $\mathrm{BM}<\mathrm{BCM}<\mathrm{CM}$, while the $\mathrm{N}$ and $\mathrm{P}$ concentrations showed an increasing order: $\mathrm{BM}>\mathrm{BCM}>\mathrm{CM}$. For litter and soil, BM had generally higher $\mathrm{N}$ and $\mathrm{P}$ concentrations than those of $\mathrm{BCM}$ and $\mathrm{CM}$. The highest $\mathrm{N}$ and $\mathrm{P}$ stock was in tree branches-not in the stem, which had the highest biomass (except for $P$ in $C M$ ). Compared with other forest types, CM stored more nutrients stored in the labile litter layer, while BM stored more nutrients stored in the stable soil layer. The net ecosystem nutrient element stock in BM was generally higher than that in BCM and $\mathrm{CM}$. The $\mathrm{C}, \mathrm{N}$ and $\mathrm{P}$ concentrations and stoichiometry in the plant organs, litter and soil were significantly correlated.

Conclusion. Our findings demonstrate that nutrient concentrations in plant organs, litter and soil are tightly linked in secondary mixed forests. 


\section{The linkages of plant, litter and soil $\mathbf{C}: \mathbf{N}: \mathbf{P}$}

2 stoichiometry and nutrient stock in different

3 secondary mixed forest types in the Qinling

4 Mountains, China

5 Yue Pang ${ }^{1}$, Jing Tian ${ }^{1}$, Xuan Zhao ${ }^{1}$, Zhi Chao ${ }^{1}$, Yuchao Wang ${ }^{2,3}$, Xinping Zhang ${ }^{4}$, Dexiang

6 Wang 1

7

$8{ }^{1}$ College of Forestry, Northwest A\&F University, Yangling, 712100, Shaanxi, China

9 'Institute of Botany of Shaanxi Province, Xi'an, Shaanxi, China

$10{ }^{3}$ Shaanxi Engineering Research Centre for Conservation and Utilization of Botanical Resources,

11 Xi'an, Shaanxi, China

$12{ }^{4}$ School of art and design, Xi'an university of technology

14 Corresponding Author:

15 Dexiang Wang ${ }^{1}$

16 College of Forestry, Northwest A\&F University (No.) 3 Taicheng Road Yangling District,

17 Shaanxi, 712100, China

18 Email address: wangdx66@sohu.com 


\section{Abstract}

21 Background. Carbon $(\mathrm{C})$, nitrogen $(\mathrm{N})$, and phosphorus $(\mathrm{P})$ stoichiometric ratios are important 22 indicators of ecosystem function and productivity. However, few studies have assessed the 23 nutrient relationship between plant, litter and soil, and the nutrient stock in different secondary 24 mixed forest types.

25 Methods. We investigated the $\mathrm{C}, \mathrm{N}$, and $\mathrm{P}$ concentrations and stoichiometric ratios in trees, 26 understory plants, litter, and soil layers in three different secondary mixed forest types (broadleaf mixed forests $(\mathrm{BM})$, broadleaf-conifer mixed forests $(\mathrm{BCM})$ and coniferous mixed forests $(\mathrm{CM})$ ) in the Qinling Mountains.

Results. The results showed that significant differences in $\mathrm{C}: \mathrm{N}: \mathrm{P}$ stoichiometry were detected in multiple organs in the vegetation layers in the different forest types. Trees, shrubs and herbs all allocated more $\mathrm{N}$ and $\mathrm{P}$ in leaves and had a higher $\mathrm{N}: \mathrm{P}$ ratio in leaves than in other organs. The $\mathrm{C}$ concentrations, $\mathrm{C}: \mathrm{N}$ ratios and $\mathrm{C}: \mathrm{P}$ ratios of all tree organs showed a decreasing order: $\mathrm{BM}<$ $\mathrm{BCM}<\mathrm{CM}$, while the $\mathrm{N}$ and $\mathrm{P}$ concentrations showed an increasing order: $\mathrm{BM}>\mathrm{BCM}>\mathrm{CM}$. For litter and soil, BM had generally higher N and P concentrations than those of BCM and CM. The highest $\mathrm{N}$ and $\mathrm{P}$ stock was in tree branches-not in the stem, which had the highest biomass (except for $\mathrm{P}$ in $\mathrm{CM}$ ). Compared with other forest types, CM stored more nutrients stored in the labile litter layer, while BM stored more nutrients stored in the stable soil layer. The net ecosystem nutrient element stock in BM was generally higher than that in BCM and $\mathrm{CM}$. The $\mathrm{C}$, $\mathrm{N}$ and $\mathrm{P}$ concentrations and stoichiometry in the plant organs, litter and soil were significantly correlated.

Conclusion. Our findings demonstrate that nutrient concentrations in plant organs, litter and soil are tightly linked in secondary mixed forests.

Keywords C:N:P stoichiometry, nutrient stock, multiple organs, nutrient element correlation, secondary mixed forest ecosystem

\section{Introduction}

48 Carbon (C), nitrogen $(\mathrm{N})$ and phosphorus $(\mathrm{P})$ are key elements for ecosystem organism 49 construction and play vital roles in ecosystem processes (Jr et al. 2006; Song et al. 2014). Many studies have reported the $\mathrm{C}, \mathrm{N}$ and $\mathrm{P}$ nutrient characteristics of vegetation, soil and litter in forest ecosystems (Cremer et al. 2016; Frédéric et al. 2010; Inagaki et al. 2004). However, these studies independently studied the nutrient characteristics of different components of the ecosystem, ignoring the correlations between components. 
54 Ecological stoichiometry, focusing on the interaction of chemical resources (elements) in the 55 biogeochemical processes, has been regarded as a scientific and effective approach for exploring 56 the feedbacks and relationships between the components in an ecosystem (Kennish 2016).

57 Previous studies have analyzed the C:N:P stoichiometric characteristics of plant organs, litter and 58 soil at regional and global scales to reveal nutrient limitations of plants, nutrient cycling and feedback relationships (Han et al. 2005; Yang et al. 2018). These studies have advanced our understanding of ecosystem stoichiometric characteristics to some extent. However, for plant stoichiometry, these studies have mainly focused on certain organs, such as leaves and roots. Within different genetic characteristics and environmental factors, different plant organs play different functional roles, resulting in differences in nutrient concentrations among organs (Kerkhoff et al. 2006; Zhang et al. 2018c), and may further lead to nutrient characteristics differences of other components in the ecosystem. Therefore, it is important to quantify nutrient element stoichiometric variation in multiple plant organs and their nutrient relationships with other components in the ecosystem, which will provide further insights into nutrient cycling and ecological model building.

Plant nutrient concentrations and their ratios are generally influenced by forest types, as different habitat and nutrient conditions can affect the plant nutrient characteristics (Jerabkova et al. 2006). Han et al. (2005) had reported that trees in deciduous forests had generally higher $\mathrm{N}$ and $\mathrm{P}$ concentration than these in coniferous forests. Further, these nutrient difference in vegetation will change the nutrient concentration of litter and soil (Capellesso et al. 2016), ultimately leading to the different nutrient stock of components among different ecosystems. Secondary forests account for $59.5 \%$ of the global forest cover and contain many forest types (Chokkalingam \& De Jong 2001; FAO 2015). Although most previous studies have analyzed soil carbon stocks, stoichiometric and nutrient resorption and diverse ecological processes in secondary forests (Fonseca et al. 2011; Kenzo et al. 2010; Zeng et al. 2017), the C, N and P nutrient patterns at the ecosystem level in different secondary mixed forest communities remain unclear. This insufficient knowledge might lead to the inaccurate estimation of secondary forest nutrient stock and underestimate the important role of secondary forests in the nutrient cycle (Attiwill \& Adams 1993; Mcdonald \& Healey 2000). Accordingly, exploring the characteristics of $\mathrm{C}, \mathrm{N}$ and $\mathrm{P}$ nutrient concentrations and stock in different secondary mixed forests is urgently needed to meet the challenge of managing $\mathrm{C}$ and nutrient stocks worldwide.

Forests in the Qinling Mountains underwent from extensive logging during the 1960s and 1970s, which promoted the regeneration of diverse secondary forests. To advance natural forest resource protection and improve the ecological environment, the Chinese government initiated the "Natural Forest Protection Program" (NFPP) (Xu et al. 2006). Now, secondary forests account for $80 \%$ of the Qinling forest area, which has become an important secondary forest area 
90 in China (Chai et al. 2016). Previous studies have analyzed the structural characteristics of the 91 community, soil nutrient characteristics, plant leaf C:N:P stoichiometry and microbial diversity 92 among these secondary forests (Hou et al. 2018; Shi et al. 2019; Zhang et al. 2018b; Zheng et al. 93 2017). However, information about the relationship of C:N:P stoichiometry between vegetation, 94 litter and soil, and effects of different mixed forest types on ecosystem C:N:P stoichiometry and 95 nutrient stock characteristics has rarely been evaluated.

In this study, we determined the $\mathrm{C}, \mathrm{N}$, and $\mathrm{P}$ concentrations and stoichiometric ratios in trees, understory plants, litter, and soil collected from three different secondary mixed forest types, namely, broadleaf mixed forests (BM), broadleaf-conifer mixed forests (BCM) and coniferous mixed forests (CM), in the Qinling Mountains. We hypothesized that the $\mathrm{C}, \mathrm{N}$ and $\mathrm{P}$ stoichiometry and nutrient stock of different plant organs, litter and soil varied among different secondary mixed forest types due to differences in genetic characteristics and environmental factors. In addition, we predicted that the $\mathrm{C}, \mathrm{N}$, and $\mathrm{P}$ concentrations in the plants, litter and soils might be highly coupled because of their cycling in the same system. Therefore, the objectives of this research were to (1) examine the $\mathrm{C}, \mathrm{N}$ and $\mathrm{P}$ concentrations and stoichiometric characteristic differences of multiple plant organs, litter and soil among different secondary mixed forest types; (2) quantify the nutrient stock capacity of the $\mathrm{C}, \mathrm{N}$ and $\mathrm{P}$ elements in different secondary mixed ecosystems; and (3) explore the relationships of C:N:P stoichiometry between the plant, litter and

\section{Materials \& Methods}

\section{Study site description}

112 The field research was conducted at the Qinling National Forest Ecosystem Research Station 113 (Huoditang Experimental Forest Farm of Northwest A\&F University) in Ningshaan County $114\left(33^{\circ} 18^{\prime}-33^{\circ} 28^{\prime} \mathrm{N}, 108^{\circ} 21^{\prime}-108^{\circ} 39^{\prime} \mathrm{E}\right)$, Shaanxi Province, China. The landform of the station is characterized by an abrupt and broken landscape, with altitudes ranging from 800 to $2500 \mathrm{~m}$ and a mean slope of approximately $35^{\circ}$. The soil in this area is composed of Cambisols, Umbrisols and Podzols (FAO), and the mean soil depth is $50 \mathrm{~cm}$ (Yu et al. 2013). This region has a subtropical humid montane climate, with an average annual precipitation of $1000 \mathrm{~mm}$. Over 50\% of the precipitation falls from July to September, and the average annual humidity is approximately $77 \%$. The average temperature is $10.5^{\circ} \mathrm{C}$, with an extreme minimum temperature of $-9.5^{\circ} \mathrm{C}$ and an extreme maximum temperature of $35^{\circ} \mathrm{C}$. The plant growth period is approximately 177 days, and the average frost-free period is approximately 199 days (Delian 2004). The forest farm covers an area of 22.25 square kilometers. The forests had been rotated felling or experienced firewood cutting between 1976 and 1978 in the Huoditang Experimental 
125 Forest Farm, and much of the area is now covered by secondary growth. Currently, the main tree 126 species in this area are Ouercus aliena var. auteserrata, Quercus variabilis, Pinus armandii, 127 Betula albosinensis, Picea asperata, Populus davidiana and other broadleaf species. Based on 128 the vegetation deforestation history and restoration status, three secondary mixed forest types 129 (BM, BCM and CM) were selected. Detailed information about each secondary mixed forest 130 type is presented in Table 1.

131

\section{Experimental design}

133 The study was conducted from July to August 2017 at the Huoditang Experimental Forest Farm. 134 All selected sites were located on similar slopes, aspects, slope gradients, and elevations. Each 135 secondary mixed forest type was represented by three independent replicate sites, and the space 136 between any two sites was large enough to exclude spatial dependence for the soil variables.

137 Three replicate plots $(20 \times 20 \mathrm{~m})$ were randomly established at each site for the subsequent plant, 138 litter and soil sampling (Fig.1). For each plant, litter and soil variable, the average value of the 139 three replicated plots was taken as the observation for the whole site. Finally, in total, 9

140 observations were established (three different secondary mixed forest types $\times$ three replicate 141 sites) for each variable.

\section{Plant, litter and soil investigation and sampling}

144 The diameter at breast height $(\mathrm{DBH} \geq 5 \mathrm{~cm}, 1.3 \mathrm{~m})$ of all trees in each plot was measured, and 145 the trees were also classified and counted by species. After that, different organ samples of trees 146 were obtained by species. Mature and healthy leaves were picked from the east, west, south and north directions of the tree crown, and branches (diameter $<1 \mathrm{~cm}$ ) were cut form the upper, middle and lower parts of the canopies. The machete and increment bore were used to obtain the bark and stem samples, respectively, at the DBH location. Roots (diameter $<1 \mathrm{~cm}$ ) were dug up from the $0-60 \mathrm{~cm}$ soil layer, and root samples were collected by removing the surrounding soil along a main root of a specific plant species until the roots appeared. These organ samples from the trees were oven dried at $70^{\circ} \mathrm{C}$ to constant weight. Based on the $\mathrm{DBH}$ and tree height, the biomass of the components (leaves, branches, stems, bark and roots) of each tree species in the three secondary mixed forest plots was calculated using published species-specific allometric equations developed for trees within or near the study area (Table S1). To better reflect the relative contributions of multiple tree species at the plot level, we first calculated the biomass of the organs of the corresponding species according to the allometric growth equation, and obtained the contribution ratio of the organs of different species. Then the different organ samples of the tree were mixed according to the ratios. 
160

161

162

163

164

165

166

167

168

169

170

171

172

173

174

175

176

177

178

179

180

181

182

183

184

185

186

187

188

189

190

191

192

193

194

Shrub and herb biomass were determined using total harvesting destructive sampling techniques. Five shrub subplots $(2 \times 2 \mathrm{~m})$ and five herb subplots $(1 \times 1 \mathrm{~m})$ were established along the diagonals of each plot for sample collection. Shrub plants were separated into leaves, stems and roots, and herbs were separated into aboveground and belowground components. For litter sampling, all organic material within five $1 \times 1 \mathrm{~m}$ subplots was collected from each plot. There were no corresponding allometric equations for shrubs and herbs in the study area, and the same components of shrubs, herbs and litter were mixed uniformly into one sample. Finally, the subsamples of shrub, herb and litter were transported to the laboratory and oven dried at $70{ }^{\circ} \mathrm{C}$ to a constant weight.

For soil sampling, nine replicate sampling points were established along an " $S$ " shape in nine plots. After removing the litter layer and biological crusts, nine soil samples at 0-20 cm, 20-40 $\mathrm{cm}$ and 40-60 $\mathrm{cm}$ were obtained separately from each point using a soil auger (400-mm inner diameter) and were fully homogenized to form one composite soil sample for each soil layer in each plot. The plant roots, fauna, and debris were removed by hand, and the gravel (rock fragments $>2 \mathrm{~mm}$ ) was reserved to measure the percentage of stones. The remaining soil samples were sieved $(<2 \mathrm{~mm})$ and air dried at room temperature for chemical property analysis. Soil bulk density (BD) samples were obtained randomly from three points per plot by volumetric rings $\left(100 \mathrm{~cm}^{3}\right)$. The nutrient element stock of $\mathrm{C}, \mathrm{N}$ and $\mathrm{P}$ in each soil layer was calculated using the following equation:

$$
\mathrm{S}_{n}=C_{n} \times B D_{n} \times L_{n} \times 10^{-1}
$$

Where $S_{n}$ is the $C, N$ and $P$ stock of soil in the $n$-th soil layer $\left(t \cdot h a^{-1}\right) ; C_{n}, B D_{n}$, and $L_{n}$ are the $C$ concentration $\left(\mathrm{mg} \cdot \mathrm{g}^{-1}\right)$, soil bulk density $\left(\mathrm{g} \cdot \mathrm{cm}^{-3}\right)$, and soil depth $(\mathrm{cm})$ of the $\mathrm{n}$-th soil layer, respectively; and $10^{-1}$ is the unit conversion factor.

\section{Plant, litter and soil physicochemical measurements}

The $\mathrm{C}, \mathrm{N}$, and $\mathrm{P}$ concentrations in the tree, shrub and herb organs and litter were analyzed after the samples were ground into a powder with a plant-sample mill (1093 Sample Mill, Hoganas, Sweden). The organic carbon (OC) contents of the plant, litter and soil samples were measured using the $\mathrm{K}_{2} \mathrm{Cr}_{2} \mathrm{O}_{7}$ oxidation method (Bao 2000). The total nitrogen (TN) and total phosphorus (TP) concentrations of the plant, litter and soil samples were determined by colorimetric method with an automatic discontinuous elemental analyzer (Clever chem200+, Germany) after digestion with $\mathrm{H}_{2} \mathrm{SO}_{4}$ and $\mathrm{H}_{2} \mathrm{O}_{2}$. The volume of gravel (rock fragments $>2 \mathrm{~mm}$ ) was measured using the drainage method. The soil BD was determined using the soil core method and obtained by calculating the ratio of soil mass to total volume $\left(\mathrm{g} \cdot \mathrm{cm}^{-3}\right)$ after oven dried at $105^{\circ} \mathrm{C}$ to a constant weight (De Vos et al. 2005). 


\section{Data analyses}

197

198

199

200

201

202

203

204

205

206

207

208

209

210

211

212

213

214

215

216

217

218

219

220

221

222

223

224

225

226

227

228

229

The total ecosystem C, N and P stock values were based on the combination of trees, shrubs, herbs, litter and soil pool. The mean and standard error of the investigated variables (e.g., $\mathrm{C}, \mathrm{N}$ and $\mathrm{P}$ concentrations, $\mathrm{C}, \mathrm{N}$ and $\mathrm{P}$ stocks, $\mathrm{C}: \mathrm{N}, \mathrm{C}: \mathrm{P}$ and N:P ratios) of plant organs, litter and soil mixtures were calculated for each organ, site and soil depth separately. Data were checked for normality and homogeneity of variance and, if necessary, were transformed. The effects of organ, soil layer and forest type on the concentration, stoichiometry and stocks of the nutrient elements $(\mathrm{C}, \mathrm{N}$ and $\mathrm{P})$ were tested using one-way ANOVA and least significant difference (LSD) multiple comparison $(\mathrm{p}<0.05)$. The Pearson correlation was used to determine the relationships of $\mathrm{C}: \mathrm{N},: \mathrm{P}$ stoichiometry between plant, litter and soil. All statistical analyses were performed using R version 3.5.0 (R Development Core Team 2018).

\section{Results}

\section{Plant and litter biomass and soil bulk density}

The biomass of plant organs was generally different among different organs and forest types (Fig. S1A, B). For total plant biomass (Table S2), the shrub total biomass in BCM (4.15 $\left.\mathrm{t} \cdot \mathrm{ha}^{-1}\right)$ was significantly higher than that in $\mathrm{CM}\left(2.26 \mathrm{t} \cdot \mathrm{ha}^{-1}\right)$, and there were no significant differences between BCM and BM $\left(3.3 \mathrm{t} \cdot h \mathrm{a}^{-1}\right)$. The herb total biomass in CM $\left(1.08 \mathrm{t} \cdot \mathrm{ha}^{-1}\right)$ was significantly higher than that in both BM $\left(0.55 \mathrm{t}^{\cdot h \mathrm{~h}^{-1}}\right)$ and BCM $\left(0.66 \mathrm{t} \cdot \mathrm{ha}^{-1}\right)$. Although the tree total biomass was nonsignificant among the three forest types, it accounted for more than $96 \%$ of the ecosystem total plant biomass in all forest types. In addition, the litter biomass in CM (5.52 $\mathrm{t} \cdot \mathrm{ha}^{-}$ $\left.{ }^{1}\right)$ was significantly higher than that in BM $\left(3.86 \mathrm{t}^{\cdot} \mathrm{ha}^{-1}\right)$ and BCM $\left(4.21 \mathrm{t} \cdot \mathrm{ha}^{-1}\right)$ (Table S2). For organ biomass (Fig. S1A, B), the highest biomass occurred in the stem for tree, root for shrub and aboveground portion for herb, ranging from 61.94-83.74 $\mathrm{t} \cdot \mathrm{ha}^{-1}, 1.50-1.88 \mathrm{t} \cdot \mathrm{ha}^{-1}, 0.24-0.46$ $\mathrm{t} \cdot \mathrm{ha} \mathrm{a}^{-1}$, respectively. Inconsistent biomass of plant organs was observed in vegetation layers among different forest types; however, it was nonsignificant.

Only in the BM was the soil BD of the $0-20 \mathrm{~cm}$ soil layer significantly lower than that of the 40-60 cm soil layer, although it was not statistically significant among the different soil layers in the BCM and CM (Fig. S1C). There was no significant difference in soil BD at the same soil layer between different forest types (Fig. S1C).

\section{C:N:P stoichiometric characteristics in ecosystem components}

The stoichiometry varied greatly in different plant organs, litter and soil layers under different forest types. In the tree layer, the $\mathrm{C}$ concentration of all organs in $\mathrm{CM}$ was notably higher than 
230 that in BM, while it was similar with BCM (Fig. 2A). The C concentration was nonsignificant 231 between different organs for all forest types (Fig. 2A). Among tree organs, the leaves and stem 232 had significantly higher and lower $\mathrm{N}$ and $\mathrm{P}$ concentrations than the other organs in all forest 233 types together (Fig. 2B, C). The $\mathrm{N}$ and $\mathrm{P}$ concentrations in all tree organs had the same pattern 234 among the different forest types, showing the increasing order of $\mathrm{BM}>\mathrm{BCM}>\mathrm{CM}$ (Fig. 2B, C). 235 Leaves and stems had the lowest and highest ratios of $\mathrm{C}: \mathrm{N}$ and $\mathrm{C}: \mathrm{P}$ for all forest types,

236

237

238

239

240

241

242

243

244

245

246

247

248

249

250

251

252

253

254

255

256

257

258

259

260

261

262

263

264

265 respectively, showing a decreasing order of $\mathrm{BM}<\mathrm{BCM}<\mathrm{CM}$ (Fig. 2D, E). The N:P ratio in leaves was notably higher than that in other organs among all forest types (except leaves and branches in CM) (Fig. 2F).The N:P ratios of branches and bark in CM were significantly higher than those of the other two forest types, while the values were typically nonsignificant in other organs in all forest types (Fig. 2F).

In the shrub layer, the highest $\mathrm{C}$ concentration was observed in the branches for the three forest types, while the highest $\mathrm{N}$ and $\mathrm{P}$ concentrations were in the leaves (Fig. 3A-C). Leaves in $\mathrm{CM}$ had significant lower and higher $\mathrm{C}$ and $\mathrm{P}$ than $\mathrm{BM}$, while branches in $\mathrm{BM}$ had significant higher $\mathrm{N}$ than the other two forests. Shrub branches and leaves had the highest and lowest ratios of $\mathrm{C}: \mathrm{N}$ and $\mathrm{C}: \mathrm{P}$ for all forest types, while the highest $\mathrm{N}: \mathrm{P}$ ratio was observed in leaves (Fig. 3DF). Branches in BM had significant lower and higher C:N and N:P than CM, while leaves in BCM had significant higher $\mathrm{C}: \mathrm{P}$ and $\mathrm{N}: \mathrm{P}$ than the other two forests. In the herb layer, the aboveground leaf $\mathrm{C}, \mathrm{N}$ and $\mathrm{P}$ concentrations were significantly higher than those in the underground root, while the aboveground leaf $\mathrm{C}: \mathrm{N}$ and $\mathrm{C}: \mathrm{P}$ ratios were significantly lower than those in underground root (except for C:P in BCM) (Fig. 3A-E). Leaves in BCM had significant higher $\mathrm{C}$ and $\mathrm{C}: \mathrm{P}$ than the other two forests, while roots in $\mathrm{BM}$ had significant higher and lower $\mathrm{P}$ and C:P. Although the herb N:P ratio was nonsignificant among different organs, it was generally higher in leaves than in roots (Fig. 3F). Leaves in BCM had significant higher N:P than the other two forests. In the litter layer, the C:N:P stoichiometric characteristics were similar to the results of the tree layer (except for $\mathrm{N}: \mathrm{P}$ ). The $\mathrm{C}$ concentration was generally higher in $\mathrm{CM}$ than in $\mathrm{BM}$ and $\mathrm{BCM}$ (Fig. 3A). The $\mathrm{N}$ and $\mathrm{P}$ concentrations in $\mathrm{BM}$ were significantly higher than those in $\mathrm{BCM}$ and $\mathrm{CM}$, while the opposite trend was observed, i.e., the $\mathrm{C}: \mathrm{N}$ and $\mathrm{C}: \mathrm{P}$ ratios were significantly lower in BM than in BCM and CM (Fig. 3B-E). BM and BCM had relatively higher N:P ratios than CM (Fig. 3F).

For the soil level, the concentrations of $\mathrm{C}, \mathrm{N}$ and $\mathrm{P}$ and the ratios of $\mathrm{C}: \mathrm{P}$ and $\mathrm{N}: \mathrm{P}$ in topsoil (0$20 \mathrm{~cm}$ ) were significantly higher than those in subsoil $(20-40 \mathrm{~cm}$ and $40-60 \mathrm{~cm})$, while the C:N ratio was nonsignificant among different soil layers (Fig. 4A-F). The $\mathrm{C}$ and $\mathrm{N}$ concentrations in $\mathrm{CM}$ were significantly lower than those in BCM and BM only in topsoil, while the $\mathrm{P}$ concentration was significantly higher in the $0-20 \mathrm{~cm}$ and $20-40 \mathrm{~cm}$ soil layers in BM than in BCM and CM (Fig. 4A-C). The C:P and N:P ratios in the $0-20 \mathrm{~cm}$ and $20-40 \mathrm{~cm}$ soil layers in 
266 BCM were significantly higher than those in BM and CM, while the C:N ratio was

267 nonsignificant among the different forest types (Fig. 4D-F).

268

269

\section{C, $\mathbf{N}$ and $\mathbf{P}$ nutrient stock in ecosystem}

270

271

272

273

274

275

276

277

278

279

280

281

282

283

284

285

286

287

288

289

290

291

292

293

294

295

296

297

298

299

300

301

The $\mathrm{C}, \mathrm{N}$ and $\mathrm{P}$ nutrient stock varied greatly in the different plant organs, litter and soil layers in the different forest types (Figs. 5-7, Tables 2-4). For the plant layer, the highest $C$ stock was observed in the stems of trees, roots of shrubs and leaves of herbs, while the highest $\mathrm{N}$ and $\mathrm{P}$ stock was generally observed in branches of trees (except for P in BCM and CM), roots of shrubs (except for $\mathrm{N}$ in $\mathrm{BCM}$ ) and leaves of herbs (Figs. 5-7A, B). The $\mathrm{C}$ stock of tree stems in $\mathrm{CM}$ was significantly higher than that in $\mathrm{BM}$, while the $\mathrm{N}$ and $\mathrm{P}$ stock values of tree branches in $\mathrm{BM}$ were significantly higher than those in BCM and CM (Figs. 5-7A). Additionally, the $\mathrm{C}, \mathrm{N}$ and $\mathrm{P}$ stock values of shrub leaves and branches in BCM were generally higher than those in the other two forest types, while the $\mathrm{C}, \mathrm{N}$ and $\mathrm{P}$ stock values of herb leaves in $\mathrm{BM}$ and $\mathrm{BCM}$ were considerably lower than those in CM (Figs. 5-7B). Regarding nutrient element stock of total plant biomass, the $\mathrm{C}, \mathrm{N}$ and $\mathrm{P}$ stock values of shrub biomass in $\mathrm{BCM}$ were generally higher than those in $\mathrm{BM}$ and $\mathrm{CM}$, while the $\mathrm{C}, \mathrm{N}$ and $\mathrm{P}$ stock values of herb biomass in $\mathrm{CM}$ were significantly higher than those in $\mathrm{BM}$ and $\mathrm{BCM}$ (Tables 2-4). The nutrient element stock of total tree biomass had the highest percentage among the plant layer, and the $\mathrm{P}$ stock of total tree biomass in BM was significantly higher than that in $\mathrm{CM}$ (Tables 2-4). For the litter layer, the share of $\mathrm{C}, \mathrm{N}$ and $\mathrm{P}$ stored in litter biomass in $\mathrm{CM}$ generally exceeded that in $\mathrm{BM}$ and $\mathrm{BCM}$ (Tables 2-4).

For the soil layer, the stock of $\mathrm{C}$ and $\mathrm{N}$ in the mineral topsoil $(0-20 \mathrm{~cm})$ was significantly higher than that in the subsoil $(20-60 \mathrm{~cm})$, while the $\mathrm{P}$ stock was nonsignificant among the different soil layers (Figs. 5-7C). Although there was no notable difference in nutrient element stock at the same soil layer among different forest types, the nutrient element stock in BM was generally higher than that in BCM and CM (Figs. 5-7C). Regarding the total soil nutrient element stock and net ecosystem nutrient element stock, the $\mathrm{C}, \mathrm{N}$ and $\mathrm{P}$ stock values were all nonsignificant under the three forest types (Tables 2-4). However, the soil layer had the highest nutrient element stock among different ecosystem components, and both the total soil nutrient element stock and the net ecosystem nutrient element stock in BM were generally higher than those in BCM and CM (Tables 2-4).

\section{Connections of C:N:P stoichiometric among ecosystem components} The C:N:P stoichiometric ratios of the plant organs responded differently to soil and litter nutrient stoichiometry (Fig. 8). SOC was significantly correlated negatively with C concentration of tree leaves, whereas it was significantly correlated positively with the $\mathrm{C}$ concentration of herb 
302

303

304

305

306

307

308

309

310

311

312

\section{Discussion}

314

315

316

317

318

319

320

321

322

323

324

325

326

327

328

329

330

331

332

333

334

335

336 ratios (Fig. 8). Zhang et al. 2018a).

leaves (Fig. 8A, C). $\mathrm{N}$ concentration in tree organs was significantly correlated positively with $\mathrm{N}$ concentration in litter and soil (except branches), while $\mathrm{P}$ concentration in tree leaves and branches was significantly correlated positively with $\mathrm{P}$ concentration in litter and soil (Fig. 8A). $\mathrm{P}$ in herb root was significantly correlated positively with $\mathrm{P}$ concentration in litter and soil (Fig. 8C). No clear relationship was observed between shrub nutrients and these in litter and soil (Fig. $8 \mathrm{~B})$. The $\mathrm{C}: \mathrm{N}$ ratios in tree organs were significantly correlated positively with that in litter and soil, while C:P was only significantly correlated positively with that in litter (Fig. 8D). N:P ratio of shrub leaves was significantly correlated positively with that in litter, and C:P of herb roots was significantly correlated positively with that in litter (Fig. 8E, F). The significant positive correlations between the litter and soil were linked by their $\mathrm{N}$ and $\mathrm{P}$ concentrations and $\mathrm{C}: \mathrm{N}$

\section{C:N:P stoichiometric characteristics in ecosystem components}

For all trees, the mean leaf $\mathrm{C}, \mathrm{N}$, and $\mathrm{P}$ contents were $484.26 \mathrm{mg} \mathrm{g}^{-1}, 15.6 \mathrm{mg} \mathrm{g}^{-1}$ and $1.86 \mathrm{mg} \mathrm{g}^{-1}$ respectively. Leaf $\mathrm{N}$ concentration was lower, while $\mathrm{P}$ concentration was higher than those of China's terrestrial plants $\left(18.6,1.21 \mathrm{mg} \mathrm{g}^{-1}\right)$ or the global flora $\left(20.1,1.77 \mathrm{mg} \mathrm{g}^{-1}\right)$ (Han et al. 2005; Reich \& Oleksyn 2004). The mean leaf $C$ of the trees was higher than that of the grassland biomes of China (438 $\mathrm{mg} \mathrm{g}^{-1}$ ) and of global flora (461 mg g $\mathrm{m}^{-1}$ ) (Elser et al. 2000; He et al. 2006). Significant differences in C:N:P stoichiometry were detected in plant organs in all forest types (Figs. 2-3). Due to genetic and evolutionary differences, plants can adjust their demand for specific nutrient elements (Gong et al. 2017), which consequently results in C:N:P stoichiometric differences between plant organs (Sistla \& Schimel 2012). Different plant functional groups (tree, shrub and herb) have a common set of rules that allocate more N and P in leaves (although $\mathrm{P}$ is not significantly higher in shrub leaves) and have a higher N:P ratio in leaves than in other organs (Figs. 2-3B, C, F). This finding aligns with previous studies showed that plant leaves had higher nutrient concentrations than non-leaf organs (Hong et al. 2014; Zhang et al. 2018c).

Leaves are responsible for many physiological functions (e.g., photosynthesis, transpiration and respiration) and require higher quantities of $\mathrm{N}$ and $\mathrm{P}$ to complete diverse biochemical processes (Minden \& Kleyer 2014). Furthermore, Leaves can maintain a relatively constant higher N:P ratio to meet the physiological needs of metabolic processes, while other organs, with $\mathrm{P}$ concentrations rising faster than $\mathrm{N}$ concentrations, have a lower N:P ratio (Kerkhoff et al. 2006;

Tree organs in $\mathrm{BM}$ had general higher $\mathrm{N}$ and $\mathrm{P}$ concentrations and general lower $\mathrm{C}$ concentrations, C:N ratios and C:P ratios than those in CM (Fig. 2A-E). These findings correspond with those of Cao and Chen (2017) and Han et al. (2005), who reported higher C 
337 concentration, $\mathrm{C}: \mathrm{N}$ ratio and $\mathrm{C}: \mathrm{P}$ ratio in coniferous than in deciduous species and higher $\mathrm{N}$ and

$338 \mathrm{P}$ concentrations in deciduous than evergreen species. Firstly, conifers have many kinds of

339 structural carbohydrates (C-rich), such as lignin, tannins and waxes, and lower $\mathrm{N}$ and $\mathrm{P}$ contents,

340 resulting in higher $\mathrm{C}$ concentrations, $\mathrm{C}: \mathrm{N}$ ratios and C:P ratios (Thomas \& Martin 2012).

341 Secondly, the higher $\mathrm{C}: \mathrm{N}$ and $\mathrm{C}: \mathrm{P}$ ratios reflect higher plant $\mathrm{N}$ and $\mathrm{P}$ use efficiency (Ge \& Xie

342 2017). Coniferous species are often confined to nutrient-limited habitats (Aerts \& Iii 1999), but

343 still maintain the accumulation and increase of biomass. Thus, the coniferous species have a

344 higher $\mathrm{N}$ and $\mathrm{P}$ utilization efficiency, leading to higher $\mathrm{C}: \mathrm{N}$ and $\mathrm{C}: \mathrm{P}$ ratios. Moreover, a previous

345 study proposed that the nutrient supply status can determine the nutrient concentrations in plant

346 organs (He et al. 2008). In our study, the soil $\mathrm{N}$ and $\mathrm{P}$ concentrations were higher in $\mathrm{BM}$ than in

347 the other forest types (Fig. 4B, C), which may have caused higher $\mathrm{N}$ and $\mathrm{P}$ contents and lower

$348 \mathrm{C}: \mathrm{N}$ and $\mathrm{C}: \mathrm{P}$ ratios in organs in $\mathrm{BM}$ than in $\mathrm{BCM}$ and $\mathrm{CM}$. In contrast, the $\mathrm{C}, \mathrm{N}$ and $\mathrm{P}$

349 concentrations and stoichiometric ratios of understory plants were also significantly different

350 among the forest types, but the concentrations were different in different organs, with no

351

consistent pattern among forest type (Fig. 3). A possible explanation for these results may be that

352 different plant functional groups show some degree of below-ground niche partitioning and have

353 different root depth distributions (Büttner \& Leuschner 1994), leading to understory plants

354 having different nutrient utilization strategies from trees, ultimately forming diverse nutrient characteristics patterns.

In the present study, the litter had similar C:N:P stoichiometric characteristics with the tree

357

358

359

360

361

362

363

364

365

366

367

368

369

370

371

372

(Fig. 3). The findings extend that of Megan et al. (2004), confirming that litter stoichiometric characteristics were generally aligned with those of plants (Megan et al. 2004). A possible explanation was that $\mathrm{BM}$ had higher soil $\mathrm{N}$ and $\mathrm{P}$ concentrations than the other two forest types, causing organs higher $\mathrm{N}$ and $\mathrm{P}$ contents and lower $\mathrm{C}: \mathrm{N}$ and $\mathrm{C}: \mathrm{P}$ ratios of plant organs in $\mathrm{BM}$, and further influenced the litter's stoichiometric characteristics (Wood et al. 2006). Simultaneously, coniferous species have higher nutrient utilization efficiency than broadleaf species, with the leaves reabsorbing more nutrients before they fall, resulting in higher $\mathrm{C}: \mathrm{N}$ and $\mathrm{C}: \mathrm{P}$ ratios and lower $\mathrm{N}$ and $\mathrm{P}$ concentrations (Ericsson 1994). Moreover, trees can produce more litter biomass than understory species annually (Liu et al. 2018) and may have dominated the nutrient characteristics of litter.

In the present study, topsoil $(0-20 \mathrm{~cm})$ had significantly higher $\mathrm{C}, \mathrm{N}$, and $\mathrm{P}$ concentrations and ratios of C:P and N:P than subsoil $(40-60 \mathrm{~cm}$ ) (Fig. 4A-C, E, F). This result is in general agreement with the results of previous studies conducted in forest and grassland systems (Prusty et al. 2009; Yang \& Chen 2017). A possible explanation for the result is that topsoil nutrients are mainly affected by the return surface litter and soil microorganisms (Jobbagy \& Jackson 2000). With increasing soil depth, the input of organic matter is limited by the permeability of the soil, and microbial decomposition activity gradually decreases (Berger et al. 2002), leading to the

PeerJ reviewing PDF | (2019:12:44136:1:1:NEW 17 Apr 2020) 
373 striking stratification characteristics of soil nutrients. Among the different forest types, the soil in

$374 \mathrm{CM}$ had generally lower $\mathrm{C}, \mathrm{N}$ and $\mathrm{P}$ concentrations and ratios of $\mathrm{C}: \mathrm{P}$ and $\mathrm{N}: \mathrm{P}$ than $\mathrm{BM}$ and $\mathrm{BCM}$

375 (Fig. 4A-C, E, F). This result may be explained by the fact that litter in BM and BCM had

376 relatively higher $\mathrm{N}$ and $\mathrm{P}$ concentrations (Fig. 3B-C), which can better stimulate microbial

377 activity and invertebrate digestion (Kerkhoff et al. 2006), ultimately benefiting litter

378 decomposition and promoting soil nutrient accumulation. Furthermore, the litter biomass in BM

379 and BCM was notably lower than that in CM (Table S2), which also supported this explanation.

380 In comparison, the $\mathrm{C}: \mathrm{N}$ ratio was nonsignificant among the different soil layers and in different

381 forest types (Fig. 4D), which may be due to the close temporal coupling of $\mathrm{C}$ and $\mathrm{N}$ contents in

382 the litter decomposition process, which is consistent with the conclusion from a secondary forest

383 study (Yang \& Luo 2011). In general, these results suggested that the content of soil $\mathrm{N}$ and $\mathrm{P}$

384 may be attributable to the forest type (Jerabkova et al. 2006).

385

386

387

388

389

390

391

392

393

394

395

396

397

398

399

400

401

402

403

404

405

406

407

408

\section{$\mathrm{C}, \mathrm{N}$ and $\mathrm{P}$ nutrient stock in ecosystem}

The highest $\mathrm{C}$ stock was observed in the stems of trees, and the highest $\mathrm{C}, \mathrm{N}$ and $\mathrm{P}$ stock values were observed in the roots of shrubs (except for $\mathrm{N}$ in BCM) and leaves of herbs (Figs. 5-7A, B). We can explain these findings by the higher levels of biomass in these plant organs (Fig. S1A, B) and the relatively higher nutrient concentration (Figs. 2-3A-C) (PEICHL et al. 2006; Yu et al. 2015). However, the highest $\mathrm{N}$ and $\mathrm{P}$ stock values in trees was not in the stem, which had the highest biomass (except for $\mathrm{P}$ in $\mathrm{CM}$ ); rather, the highest values were generally in branches (Figs. 6-7A). This result corresponds with the results of Frédéric et al. (2010), who reported that the contribution of stem wood to total nutrient stock was generally lower than its contribution to total biomass. Among the different forest types, the nutrient stock of different organs and the total biomass nutrient stock were significantly different in the vegetation layers (Figs. 5-7A, B and Tables 2-4). This result is most likely associated with the diversity of species composition, biomass and nutrient concentration, which together determined the nutrient stock in the plant organs and different vegetation layers (Frédéric et al. 2010; Gong et al. 2017).

Our study suggested that $\mathrm{C}, \mathrm{N}$ and $\mathrm{P}$ stock in litter biomass in CM generally exceeded that in the BM and BCM (Tables 2-4). This finding agrees with previous studies found that, compared with broadleaf tree species, conifers tend to store a relatively higher amounts of nutrient elements in a labile litter layer (Cremer et al. 2016). Because conifer litter had higher lignin and $\mathrm{C} / \mathrm{N}$ ratios and lower $\mathrm{Ca}$ concentrations than broadleaf trees, litter decomposition and nutrient release were hampered in conifer forest (Hobbie et al. 2006). The stock of $\mathrm{C}$ and $\mathrm{N}$ in the topsoil was significantly higher than that in the subsoil because of the addition of litter fall from the more diverse canopy of trees and understory to the surface soil (Kassa et al. 2017). In contrast, the P stock was nonsignificant among the different soil layers (Fig. 7C). Soil P mainly comes from the weathering of soil rock parent material, which is a very slow process, thereby leading to 
409 relatively stable P stock under different soil layers (Tian et al. 2010). Nutrient element stock in 410 different soil layers in BM was generally higher than that in BCM and CM (Figs. 5-7C). This

411 result matches the previous conclusions that the annual litter biomass of aboveground and 412 underground components in broadleaf forest is higher than that in coniferous forest (Finer et al.

413 2007; Li et al. 2005), and the broadleaf forest have more decomposable components and soil

414 biological activity (Augusto et al. 2015), which enhances the soil C, N and P stock. In total, these

415 results indicate divergent forest nutrient conservation strategies, in which CM share more

416 nutrients stored in the labile litter layer and BM share more nutrients stored in the stable soil 417 layer.

418 In this study, the $\mathrm{N}$ and $\mathrm{P}$ stock in the plant layers were $0.746-0.486 \mathrm{t} \cdot \mathrm{ha}^{-1}$ and $0.180-0.095$ $419 \mathrm{t} \cdot \mathrm{ha}^{-1}$ respectively, larger than those of China's mangrove forest ( $\left.\mathrm{Li} 1997\right)$. And $\mathrm{C}$ stock in the 420 plant layer was $73.75-84.78 \mathrm{t} \cdot \mathrm{ha}^{-1}$, also larger than that in Asia temperate conifer forests 421 (Thurner et al. 2014). These higher level plant nutrient stock indicated the strong resilience of 422 these secondary forests. But, the nutrient stock of the soil layer and the whole ecosystem were 423 generally lower than those of the forests on the Loess Plateau in China and other forest around 424 the world (Cao et al. 2016; Lilienfein \& Wilcke 2003), which implying potential enormous 425 nutrient accumulation. Net ecosystem nutrient element stock in BM was generally higher than 426 that in BCM and CM but with nonsignificant differences (Tables 2-4). This result agrees with the 427 conclusion drawn from a previous study, in which the stock of the $\mathrm{C}, \mathrm{N}$ and $\mathrm{N}$ elements in the coniferous forest was generally lower than that of deciduous species (Cao et al. 2016). However, for nonsignificant differences, this result may be because the community is in the initial stage of succession and has lower nutrient stock in aboveground organism components in our study area

431 (Jiang et al. 2017).

432

\section{Connections of C:N:P stoichiometric among ecosystem components}

Plant, litter and soil are closely linked and interact with each other in nature ecosystems; however, few examples have been reported to show how the concentrations of $\mathrm{C}, \mathrm{N}$, and $\mathrm{P}$ in litter and soil were related to their concentrations in multiple organs of plants (Zhang et al. 2018a). Our results show that $\mathrm{C}$ concentration in tree leaves was significantly positively correlated with SOC; however, $\mathrm{C}$ concentration in herb leaves was significantly correlated positively with SOC. Previous study reported that the proper C:N ratio (closed to 25) can promote microbial metabolism and the accumulation of soil nutrients (Mooshammer et al. 2014). In the present study, tree leaves had generally higher $\mathrm{C}: \mathrm{N}$ ratio $(>25)$ and herb leaves had proper

442 C:N ratio (Fig. S2). Thus, tree leaves may inhibit microbial metabolism and the accumulation of 443 SOC, and herb leaves stimulated SOC accumulation, leading to a negative correlation between 444 SOC and $\mathrm{C}$ content in tree leaves, and a positive correlation between $\mathrm{C}$ content in herbal leaves. 
445 The connection between tree organs and soil (linked by N, P and C:N) is different from that

446 between herbs and soil (linked by P), indicating that the strategy of nutrient utilization varied by 447 plant functional groups (Zhang et al. 2019). However, there was no obvious correlation between 448 nutrients of shrub and these in soil and litter. A possible explanation is that shrubs are often 449 passively disturbed by herbivores in our study area, causing changes in the nutrient status of the 450 shrubs, which eventually leads to decouple of the cycling of shrub nutrients with soil nutrients. 451 Earlier study reported that the decoupling of nutrient cycling relationships among different 452 components of the ecosystem can be observed when plants respond passively to external 453 environmental conditions (Ladanai et al. 2010), supported our result. The strong stoichiometric 454 relationship between vegetation and litter, litter and soil were consistent with previous studies 455 (Zhang et al. 2017), likely because a large proportion of the nutrients in the litter came from 456 plant nutrients and then would be released into the soil, and finally used by vegetation. Overall, 457 our results suggested that nutrient concentrations and stoichiometry in multiple plant organs, 458 litter and soil are tightly linked in forest ecosystem.

\section{Conclusions}

460 Our study suggests that nutrient stoichiometric ratios and nutrient stock were significantly 461 different for different components and the elements of $\mathrm{C}, \mathrm{N}$, and $\mathrm{P}$ are tightly coupled between the plants, litters and soils in the secondary mixed forest ecosystems. All plants allocated the more $\mathrm{N}$ and $\mathrm{P}$ to leaves. The content of soil $\mathrm{N}$ and $\mathrm{P}$ may be related to the forest type due to vegetation nutrient concentration difference. $\mathrm{BM}$ has more advantages in terms of $\mathrm{C}, \mathrm{N}$ and $\mathrm{P}$ nutrient stock than do BCM and CM in the secondary succession community. The differences correlation between multi-plant organs, litter and soil indicate that different plant functional groups have diverse strategy of nutrient utilization. Collectively, our findings provide valuable data for forest nutrient element stock management and establishing a nutrient cycle model.

\section{Acknowledgements}

470

471

472

\section{Funding}

474 This research was supported by the National Natural Science Foundation of China 475 (No.31470644) and CFERN \& GENE Award Funds on Ecological Paper.

\section{Competing Interests}


478 The authors declare there are no competing interests.

479

\section{Author Contributions}

481 Yue Pang designed the experiment; Yue Pang, Jing Tian carried out the field work and analyzed 482 the data; Yue Pang wrote the manuscript; and Xuan Zhao, Zhi Chao, Yuchao Wang, Xinping 483 Zhang and Dexiang Wang revising the draft manuscript.

484

485

\section{References}

486

487

488

489

490

491

492

493

494

495

496

497

498

499

500

501

502

503

504

505

506

507

508

509

510

Aerts R, and Iii FSC. 1999. The Mineral Nutrition of Wild Plants Revisited: A Re-evaluation of Processes and Patterns. Advances in Ecological Research 30:1-67. https://doi.org/10.1016/S0065-2504(08)60016-1

Attiwill PM, and Adams MA. 1993. Nutrient cycling in forests. New Phytologist 124:561-582. https://doi.org/10.1111/j.1469-8137.1993.tb03847.x

Augusto L, De SA, Vesterdal L, Smolander A, Prescott C, and Ranger J. 2015. Influences of evergreen gymnosperm and deciduous angiosperm tree species on the functioning of temperate and boreal forests. Biological Reviews 90:444-466. https://doi.org/10.1111/brv.12119

Bao S. 2000. Soil and agricultural chemistry analysis. China agriculture press, Beijing.

Berger TW, Neubauer C, and Glatzel G. 2002. Factors controlling soil carbon and nitrogen stores in pure stands of Norway spruce (Picea abies) and mixed species stands in Austria. Forest Ecology and Management 159:3-14. https://doi.org/10.1016/S0378-1127(01)00705-8

Büttner V, and Leuschner C. 1994. Spatial and temporal patterns of fine root abundance in a mixed oak-beech forest. Forest Ecology and Management 70:11-21. https://doi.org/10.1016/0378-1127(94)90071-X

Cao Y, and Chen Y. 2017. Ecosystem C:N:P stoichiometry and carbon storage in plantations and a secondary forest on the Loess Plateau, China. Ecological Engineering 105:125-132. https://doi.org/10.1016/j.ecoleng.2017.04.024

Cao Y, Wang B, Wei T, and Ma H. 2016. Ecological stoichiometric characteristics and element reserves of three stands in a closed forest on the Chinese loess plateau. Environmental Monitoring and Assessment 188:80. https://doi.org/10.1007/s10661-015-5057-6

Capellesso ES, Scrovonski KL, Zanin EM, Hepp LU, Bayer C, and Sausen TL. 2016. Effects of forest structure on litter production, soil chemical composition and litter-soil interactions. Acta Botanica Brasilica 30:329-335. https://doi.org/10.1590/0102-33062016abb0048 
511 Chai Z, Sun C, Wang D, and Liu W. 2016. Interspecific associations of dominant tree

512

513

514

515

516

517

518

519

520

521

522

523

524

525

526

527

528

529

530

531

532

533

534

535

536

537

538

539

540

541

542

543

544

545

546 populations in a virgin old-growth oak forest in the Qinling Mountains, China. Botanical Studies 57:23. https://doi.org/10.1186/s40529-016-0139-5

Chokkalingam U, and De Jong W. 2001. Secondary forest: a working definition and typology. The International Forestry Review 3:19-26. https://www.jstor.org/stable/42609342

Cremer M, Kern NV, and Prietzel J. 2016. Soil organic carbon and nitrogen stocks under pure and mixed stands of European beech, Douglas fir and Norway spruce. Forest Ecology and Management 367:30-40. https://doi.org/10.1016/j.foreco.2016.02.020

De Vos B, Van Meirvenne M, Quataert P, Deckers J, and Muys B. 2005. Predictive quality of pedotransfer functions for estimating bulk density of forest soils. Soil Science Society of America Journal 69:500-510. https://doi.org/10.2136/sssaj2005.0500

Delian W. 2004. Studies on runoff and its water quality in the forestry watershed of Huoditang in Qingling Mountain. Northwest Agriculture and Forestry University of Science and Technology.

Elser JJ, Fagan WF, Denno RF, Dobberfuhl DR, Folarin A, Huberty A, Interlandi S, Kilham SS, McCauley E, and Schulz KL. 2000. Nutritional constraints in terrestrial and freshwater food webs. Nature 408:578-580. https://doi.org/10.1038/35046058

Ericsson T. 1994. Nutrient dynamics and requirements of forest crops. New Zealand Journal of Forestry Science 24:133-168.

FAO. 2015. Global Forest Resources Assessment 2015 Rome: The Food and Agricultural Organization of the United Nations (FAO).

Finer L, Helmisaari HS, K, Majdi H, Brunner I, Borja I, Eldhuset T, Godbold D, Grebenc T, Konopka B, and Kraigher H. 2007. Variation in fine root biomass of three European tree species: beech (Fagus sylvatica L.), Norway spruce (Picea abies L. Karst.), and Scots pine (Pinus sylvestris L.). Giornale Botanico Italiano 141:394-405. https://doi.org/10.1080/11263500701625897

Fonseca W, Benayas JMR, and Alice FE. 2011. Carbon accumulation in the biomass and soil of different aged secondary forests in the humid tropics of Costa Rica. Forest Ecology and Management 262:1400-1408. https://doi.org/10.1016/j.foreco.2011.06.036

Frédéric A, Mathieu J, and Quentin P. 2010. Biomass and nutrient content of sessile oak (Quercus petraea (Matt.) Liebl.) and beech (Fagus sylvatica L.) stem and branches in a mixed stand in southern Belgium. Science of the Total Environment 408:2285-2294. https://doi.org/10.1016/j.scitotenv.2010.02.040

Ge J, and Xie Z. 2017. Leaf litter carbon, nitrogen, and phosphorus stoichiometric patterns as related to climatic factors and leaf habits across Chinese broad-leaved tree species. Plant Ecology 218:1063-1076. https://doi.org/10.1007/s11258-017-0752-8 
547 Gong Y, Lv G, Guo Z, Chen Y, and Cao J. 2017. Influence of aridity and salinity on plant

548

549

550

551

552

553

554

555

556

557

558

559

560

561

562

563

564

565

566

567

568

569

570

571

572

573

574

575

576

577

578

579

580

581

582 nutrients scales up from species to community level in a desert ecosystem. Scientific Reports 7:6811. https://doi.org/10.1038/s41598-017-07240-6

Han W, Fang J, Guo D, and Zhang Y. 2005. Leaf nitrogen and phosphorus stoichiometry across 753 terrestrial plant species in China. New Phytologist 168:377-385. https://doi.org/10.1111/j.1469-8137.2005.01530.x

He J-S, Wang L, Flynn DFB, Wang X, Ma W, and Fang J. 2008. Leaf nitrogen:phosphorus stoichiometry across Chinese grassland biomes. Oecologia 155:301-310. https://doi.org/10.1007/s00442-007-0912-y

He JS, Fang J, Wang Z, Guo D, Flynn DF, and Geng Z. 2006. Stoichiometry and large-scale patterns of leaf carbon and nitrogen in the grassland biomes of China. Oecologia 149:115122. https://doi.org/10.1007/s00442-006-0425-0

Hobbie SE, Reich PB, Jacek O, Megan O, Roma Z, Cynthia H, and Piotr K. 2006. Tree species effects on decomposition and forest floor dynamics in a common garden. Ecology 87:22882297. https://doi.org/10.2307/20069230

Hong J, Wang X, and Wu J. 2014. Stoichiometry of root and leaf nitrogen and phosphorus in a dry alpine steppe on the Northern Tibetan Plateau. PLoS One 9:e109052. https://doi.org/10.1371/journal.pone.0109052

Hou L, Dong Z, Yang Y, Zhang D, Zhang S, and Zhang S. 2018. Applying foliar stoichiometric traits of plants to determine fertilization for a mixed pine-oak stand in the Qinling Mountains, China. PeerJ 6:e4628. https://doi.org/10.7717/peerj.4628

Inagaki Y, Miura S, and Kohzu A. 2004. Effects of forest type and stand age on litterfall quality and soil $\mathrm{N}$ dynamics in Shikoku district, southern Japan. Forest Ecology and Management 202:107-117. https://doi.org/10.1016/j.foreco.2004.07.029

Jerabkova L, Prescott CE, and Kishchuk BE. 2006. Nitrogen availability in soil and forest floor of contrasting types of boreal mixedwood forests. Canadian Journal of Forest Research 36:112-122. https://doi.org/10.1139/x05-220

Jiang P, Chen Y, and Cao Y. 2017. C:N:P Stoichiometry and Carbon Storage in a NaturallyRegenerated Secondary Quercus variabilis Forest Age Sequence in the Qinling Mountains, China. Forests 8:281. https://doi.org/10.3390/f8080281

Jobbagy EG, and Jackson RB. 2000. The Vertical Distribution of Soil Organic Carbon and Its Relation to Climate and Vegetation. Ecological Applications 10:423. https://doi.org/10.1890/1051-0761(2000)010[0423:tvdoso]2.0.co;2

Jr RAC, Currie WS, and Townsend PA. 2006. Carbon sequestration and nutrient cycling implications of the evergreen understory layer in Appalachian forests. Forest Ecology and Management 231:63-77. https://doi.org/10.1016/j.foreco.2006.04.040 
583 Kassa H, Dondeyne S, Poesen J, Frankl A, and Nyssen J. 2017. Impact of deforestation on soil 584 fertility, soil carbon and nitrogen stocks: the case of the Gacheb catchment in the White $585 \quad$ Nile Basin, Ethiopia. Agriculture, Ecosystems \& Environment 247:273-282.

586

587 https://doi.org/10.1016/j.agee.2017.06.034

588

Kennish MJ. 2016. Encyclopedia of Estuaries. Encyclopedia of Earth Sciences Series.

589 https://doi.org/10.1007/978-94-017-8801-4_15

Kenzo T, Ichie T, Hattori D, Kendawang JJ, Sakurai K, and Ninomiya I. 2010. Changes in 590 above- and belowground biomass in early successional tropical secondary forests after

591

592

593

594

595 shifting cultivation in Sarawak, Malaysia. Forest Ecology and Management 260:875-882.

596 https://doi.org/10.1016/j.foreco.2010.06.006

Kerkhoff AJ, Fagan WF, Elser JJ, and Enquist BJ. 2006. Phylogenetic and Growth Form Variation in the Scaling of Nitrogen and Phosphorus in the Seed Plants. The American Naturalist 168:E103-E122. https://doi.org/10.1086/507879

Ladanai S, Ågren GI, and Olsson BA. 2010. Relationships Between Tree and Soil Properties in 597 Picea abies and Pinus sylvestris Forests in Sweden. Ecosystems 13:302-316.

598

599 https://doi.org/10.1007/s10021-010-9319-4

Li M. 1997. Nutrient dynamics of a Futian mangrove forest in Shenzhen, South China. Estuarine, 600 Coastal and Shelf Science 45:463-472. https://doi.org/10.1006/ecss.1996.0201

601

602

603

604

605

Li ZA, Zou B, Xia H, Ren H, Mo J, and Weng H. 2005. Litterfall dynamics of an evergreen

606

607

608

609

610

611 broadleaf forest and a pine forest in the subtropical reigon of China. Forest Science 6:608615.

Lilienfein J, and Wilcke W. 2003. Element storage in native, agri-, and silvicultural ecosystems of the Brazilian savanna. Plant and Soil 254:425-442. https://doi.org/10.1023/A:1025579932395

Liu J, Yang Z, Peng D, Zhu H, Yang G, Ha VN, and Zhong Z. 2018. Response of soil microbial community dynamics to Robinia pseudoacacia L. afforestation in the loess plateau: a

612 Mountains of Jamaica. Forest Ecology and Management 139:257-278.

613

614 https://doi.org/10.1016/s0378-1127(00)00442-4

615

616 chronosequence approach. Plant and Soil 423:327-338. https://doi.org/10.1007/s11104-0173516-2

Mcdonald MA, and Healey JR. 2000. Nutrient cycling in secondary forests in the Blue

Megan EM, Tanguy D, and Lars OH. 2004. Scaling of C:N:P stoichiometry in forest worldwide: implications of terrestrial Redfield-type ratios. Ecology 85:2390-2401.

618 https://doi.org/10.1890/03-0351

Minden V, ., and Kleyer M, . 2014. Internal and external regulation of plant organ stoichiometry. Plant Biology 16:897-907. https://doi.org/10.1111/plb.12155 
619 Mooshammer M, Wanek W, Hämmerle I, Fuchslueger L, Hofhansl F, Knoltsch A, Schnecker J,

620

621

622

623

624

625

626

627

628

629

630

631

632

633

634

635

636

637

638

639

640

641

642

643

644

645

646

647

648

649

650

651

652

653

654

Takriti M, Watzka M, and Wild B. 2014. Adjustment of microbial nitrogen use efficiency to carbon: nitrogen imbalances regulates soil nitrogen cycling. Nature communications 5:3694. https://doi.org/10.1038/ncomms4694

PEICHL, Matthias, and Arain A. 2006. Above-and belowground ecosystem biomass and carbon pools in an age-sequence of temperate pine plantation forests. Agricultural and Forest Meteorology 140:51-63. https://doi.org/10.1016/j.agrformet.2006.08.004

Prusty BAK, Chandra R, and Azeez PA. 2009. Distribution of carbon, nitrogen, phosphorus, and sulfur in the soil in a multiple habitat system in India. Australian Journal of Soil Research 47:177-189. https://doi.org/10.1071/SR08087

Reich PB, and Oleksyn J. 2004. Global patterns of plant leaf N and P in relation to temperature and latitude. Proceedings of the National Academy of Sciences 101:11001-11006. https://doi.org/10.1073/pnas.0403588101

Shi H, Xie F, Zhou Q, Shu X, Zhang K, Dang C, Feng S, Zhang Q, and Dang H. 2019. Effects of Topography on Tree Community Structure in a Deciduous Broad-Leaved Forest in NorthCentral China. Forests 10:53. https://doi.org/10.3390/f10010053

Sistla SA, and Schimel JP. 2012. Stoichiometric flexibility as a regulator of carbon and nutrient cycling in terrestrial ecosystems under change. New Phytologist 196:68-78. https://doi.org/10.1111/j.1469-8137.2012.04234.x

Song Z, Liu H, Zhao F, and Xu C. 2014. Ecological stoichiometry of N:P:Si in China's grasslands. Plant and Soil 380:165-179. https://doi.org/10.1007/s11104-014-2084-y

Thomas SC, and Martin AR. 2012. Carbon Content of Tree Tissues: A Synthesis. Forests 3:332352. https://doi.org/10.3390/f3020332

Thurner M, Beer C, Santoro M, Carvalhais N, Wutzler T, Schepaschenko D, Shvidenko A, Kompter E, Ahrens B, and Levick SR. 2014. Carbon stock and density of northern boreal and temperate forests. Global Ecology and Biogeography 23:297-310. https://doi.org/10.1111/geb.12125

Tian H, Chen G, Zhang C, and Hall MCAS. 2010. Pattern and variation of C:N:P ratios in China"s soils: a synthesis of observational data. Biogeochemistry 98:139-151. https://doi.org/10.2307/40647956

Wood TE, Lawrence D, and Clark DA. 2006. Determinants of leaf litter nutrient cycling in a tropical rain forest: soil fertility versus topography. Ecosystems 9:700-710. https://doi.org/10.1007/s10021-005-0016-7

$\mathrm{Xu}$ J, Yin R, Zhou L, and Liu C. 2006. China's ecological rehabilitation: Unprecedented efforts, dramatic impacts, and requisite policies. Ecological Economics 57:595-607. https://doi.org/10.1016/j.ecolecon.2005.05.008 
655 Yang C, and Chen Y. 2017. Coupling of plant and soil C:N:P stoichiometry in black locust 656 (Robinia pseudoacacia) plantations on the Loess Plateau, China. Trees 31:1559-1570. 657 https://doi.org/10.1007/s00468-017-1569-8

658 Yang Y, Liu B-R, and An S-S. 2018. Ecological stoichiometry in leaves, roots, litters and soil 659 among different plant communities in a desertified region of Northern China. Catena $660 \quad 166: 328-338$. https://doi.org/10.1016/j.catena.2018.04.018

661

662

663

664

665

666

667

668

669

670

671

672

673

674

675

676

677

678

679

680

681

682

683

684

685

686

687

688

689

690

Yang Y, and Luo Y. 2011. Carbon : nitrogen stoichiometry in forest ecosystems during stand development. Global Ecology and Biogeography 20:354-361. https://doi.org/10.1111/j.1466-8238.2010.00602.x

Yu F, Wang D, Shi X, Yi X, and Li G. 2013. Seed dispersal by small rodents favors oak over pine regeneration in the pine-oak forests of the Qinling mountains, China. Scandinavian Journal of Forest Research 28:540-549. https://doi.org/10.1080/02827581.2013.794250

Yu JB, Liu JS, Meixner FX, Wang JD, Gao YJ, Wang Y, Qi XN, and Chen XB. 2015. Estimating Net Primary Productivity and Nutrient Stock in Plant in Freshwater Marsh, Northeastern China. CLEAN - Soil, Air, Water 38:1080-1086. https://doi.org/10.1002/clen.201000294

Zeng Y, Fang X, Xiang W, Deng X, and Peng C. 2017. Stoichiometric and nutrient resorption characteristics of dominant tree species in subtropical Chinese forests. Ecology and Evolution 7:11033-11043. https://doi.org/10.1002/ece3.3527

Zhang G, Zhang P, Peng S, Chen Y, and Cao Y. 2017. The coupling of leaf, litter, and soil nutrients in warm temperate forests in northwestern China. Scientific Reports 7:11754. https://doi.org/10.1038/s41598-017-12199-5

Zhang J, Zhao N, Liu C, Yang H, Li M, Yu G, Wilcox K, Yu Q, He N, and Niu S. 2018a. C:N:P stoichiometry in China's forests: From organs to ecosystems. Functional Ecology 32:50-60. https://doi.org/10.1111/1365-2435.12979

Zhang K, Cheng X, Xiao S, Yi L, and Zhang Q. 2018b. Linking soil bacterial and fungal communities to vegetation succession following agricultural abandonment. Plant and Soil 431:19-36. https://doi.org/10.1007/s11104-018-3743-1

Zhang Q, Xiong G, Li J, Lu Z, Li Y, Xu W, Wang Y, Zhao C, Tang Z, and Xie Z. 2018c. Nitrogen and phosphorus concentrations and allocation strategies among shrub organs: the effects of plant growth forms and nitrogen-fixation types. Plant and Soil 427:305-319. https://doi.org/10.1007/s11104-018-3655-0

Zhang W, Liu W, Xu M, Deng J, Han X, Yang G, Feng Y, and Ren G. 2019. Response of forest growth to C:N:P stoichiometry in plants and soils during Robinia pseudoacacia afforestation on the Loess Plateau, China. Geoderma 337:280-289. https://doi.org/10.1016/j.geoderma.2018.09.042 
691 Zheng X, Yuan J, Zhang T, Hao F, Jose S, and Zhang S. 2017. Soil Degradation and the Decline 692 of Available Nitrogen and Phosphorus in Soils of the Main Forest Types in the Qinling 693 Mountains of China. Forests 8:460. https://doi.org/10.3390/f8110460 
Figure 1

Geographic location of the Huoditang Experimental Forest Farm and the sampling plots.

BM: broadleaf mixed forests, BCM: broadleaf-conifer mixed forests, CM: coniferous mixed forests.

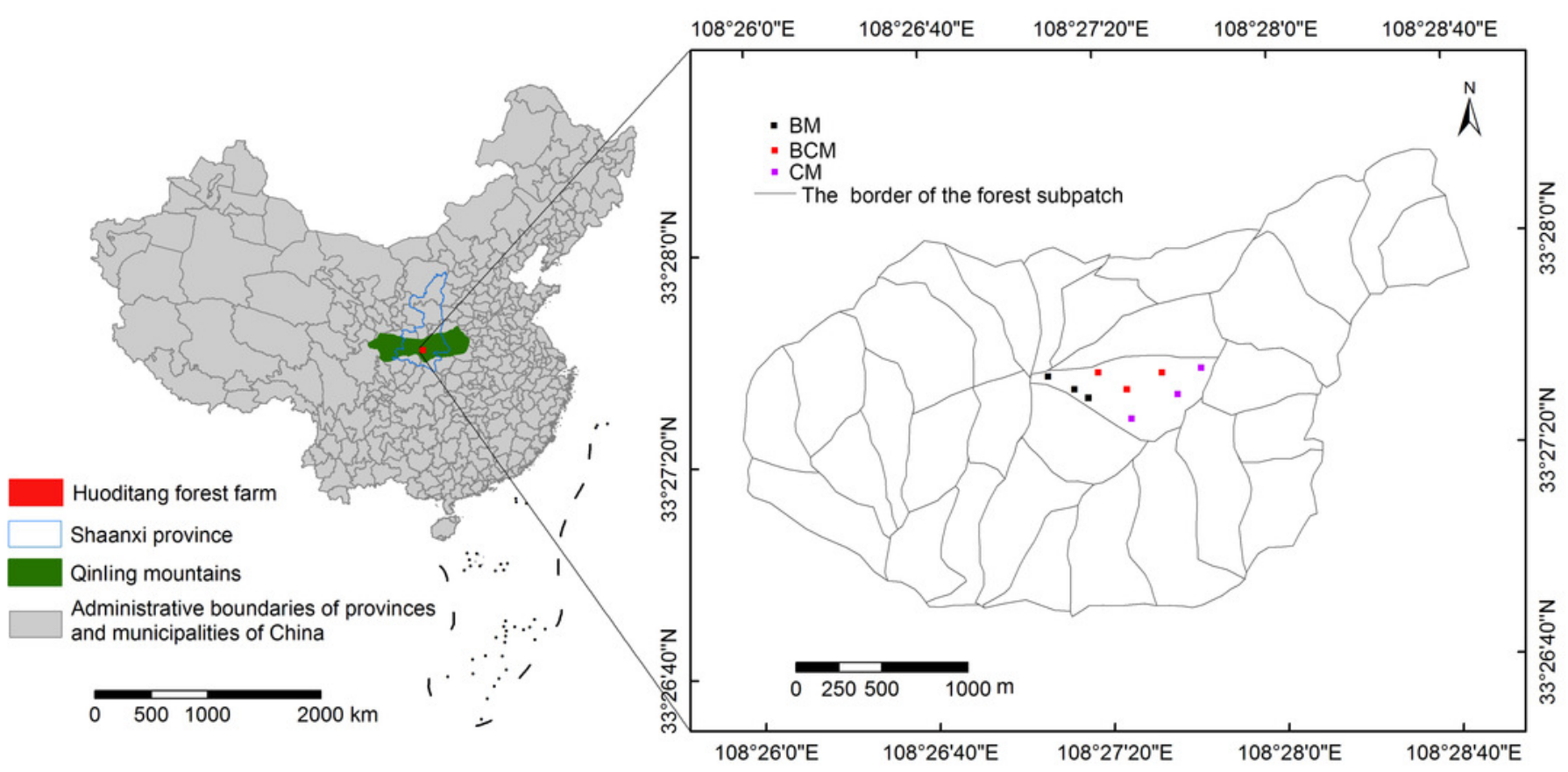




\section{Figure 2}

Stoichiometric characteristics of tree organ $\mathrm{C}, \mathrm{N}$, and $\mathrm{P}$ in three secondary mixed forests.

Different lowercase letters above the bars indicate significant differences among different forest types for the same organ $(p<0.05)$, while different uppercase letters indicate significant differences among different organs for the same forest type $(p<0.05)$. BM: broadleaf mixed forests, BCM: broadleaf-conifer mixed forests, CM: coniferous mixed forests. 

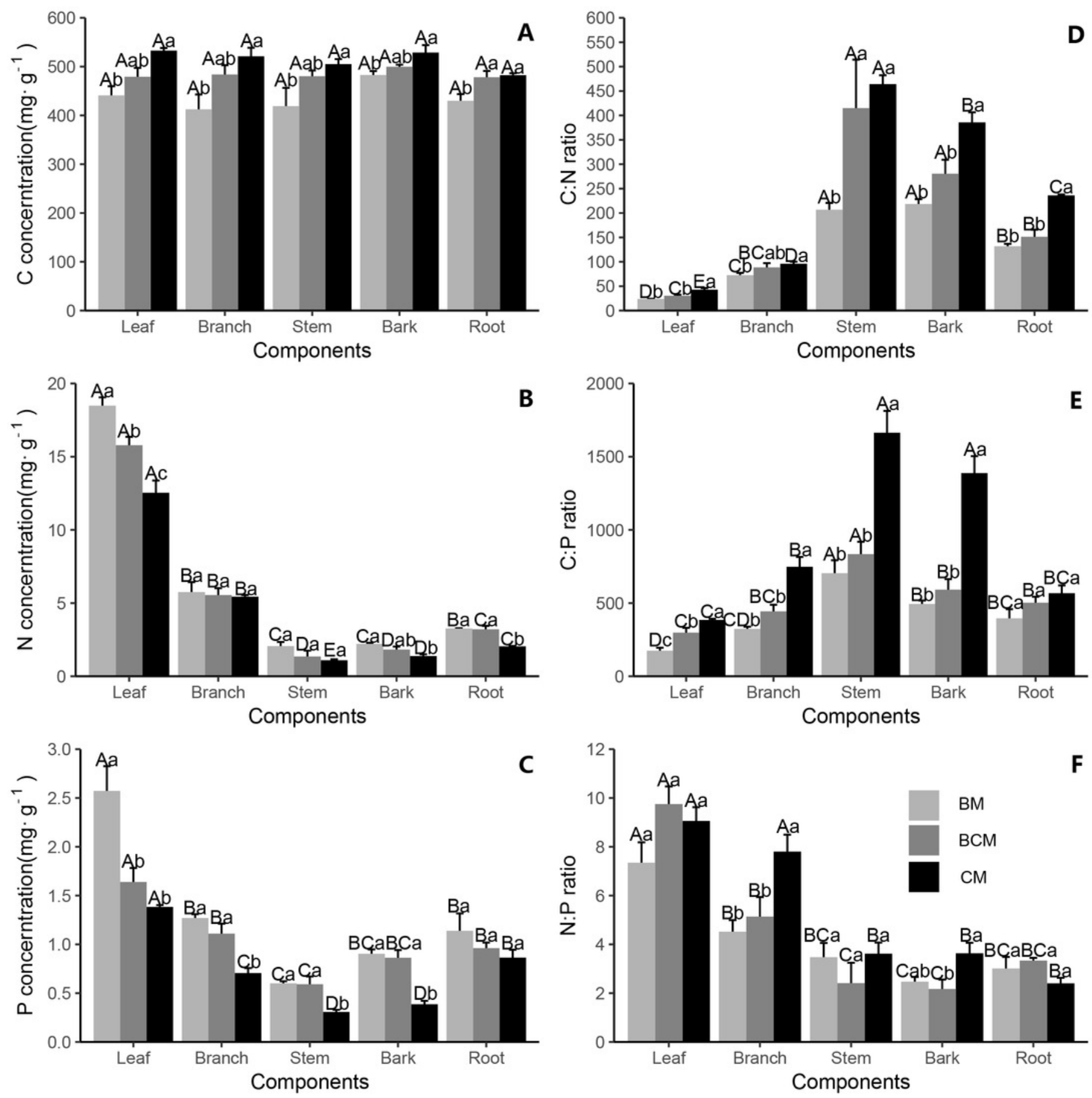


\section{Figure 3}

Stoichiometric characteristics of shrub and herb organs and litter layer $\mathrm{C}, \mathrm{N}$, and P in three secondary mixed forests.

Different lowercase letters above the bars indicate significant differences among different forest types for the same organ $(p<0.05)$, while different uppercase letters indicate significant differences among different organs for the same forest type $(p<0.05)$. SL: shrub leaf, SB: shrub branch, SR: shrub root, HA: herb aboveground, HU: herb underground, GL: ground litter. BM: broadleaf mixed forests, BCM: broadleaf-conifer mixed forests, CM: coniferous mixed forests. 

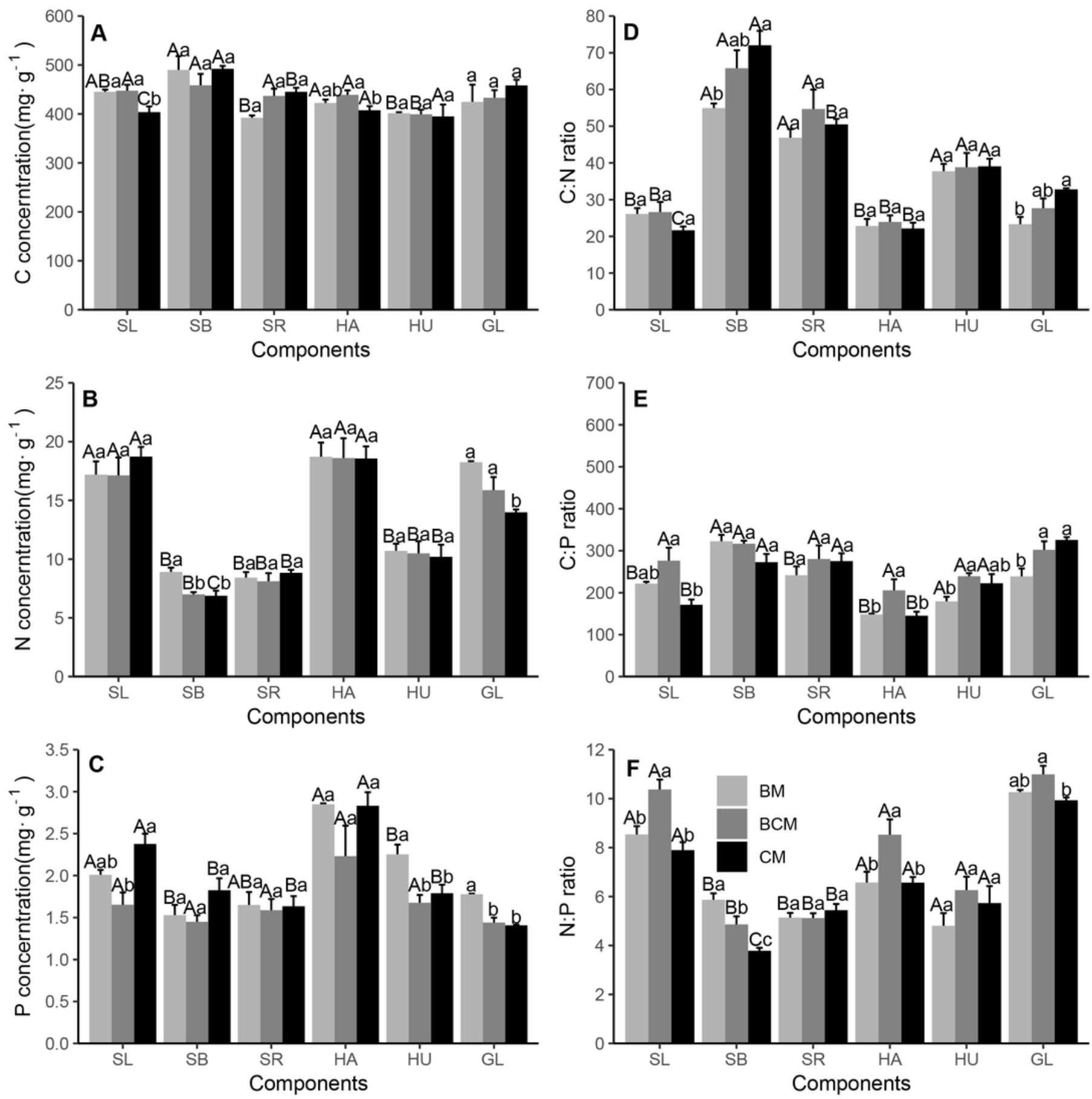


\section{Figure 4}

Stoichiometric characteristics of soil layer $\mathrm{C}, \mathrm{N}$, and $\mathrm{P}$ in three secondary mixed forests.

Different lowercase letters above the bars indicate significant differences among different forest types for the same soil layer $(p<0.05)$, while different uppercase letters indicate significant differences among different soil layers for the same forest type $(p<0.05)$. BM: broadleaf mixed forests, BCM: broadleaf-conifer mixed forests, CM: coniferous mixed forests. 

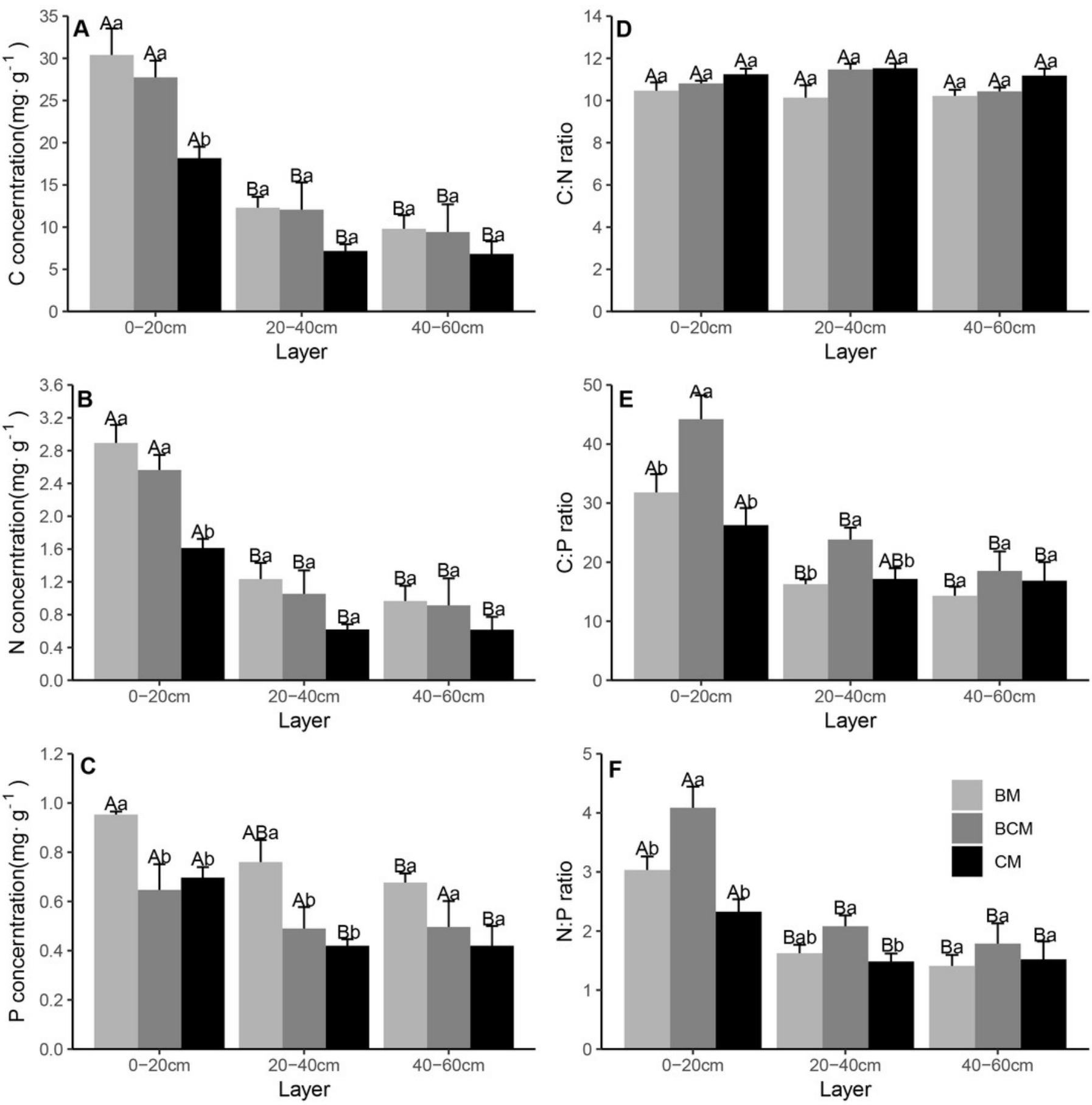


\section{Figure 5}

Carbon storage of trees (A), understory plants (B) organs and soil layers (C) in three secondary mixed forests.

Different lowercase letters above the bars indicate significant differences among different forest types for the same organ or soil layer $(p<0.05)$, while different uppercase letters indicate significant differences among different organs or soil layers for the same forest type $(p<0.05)$. SL: shrub leaf, SB: shrub branch, SR: shrub root, HA: herb aboveground, HU: herb underground. BM: broadleaf mixed forests, BCM: broadleaf-conifer mixed forests, $\mathrm{CM}$ : coniferous mixed forests. 

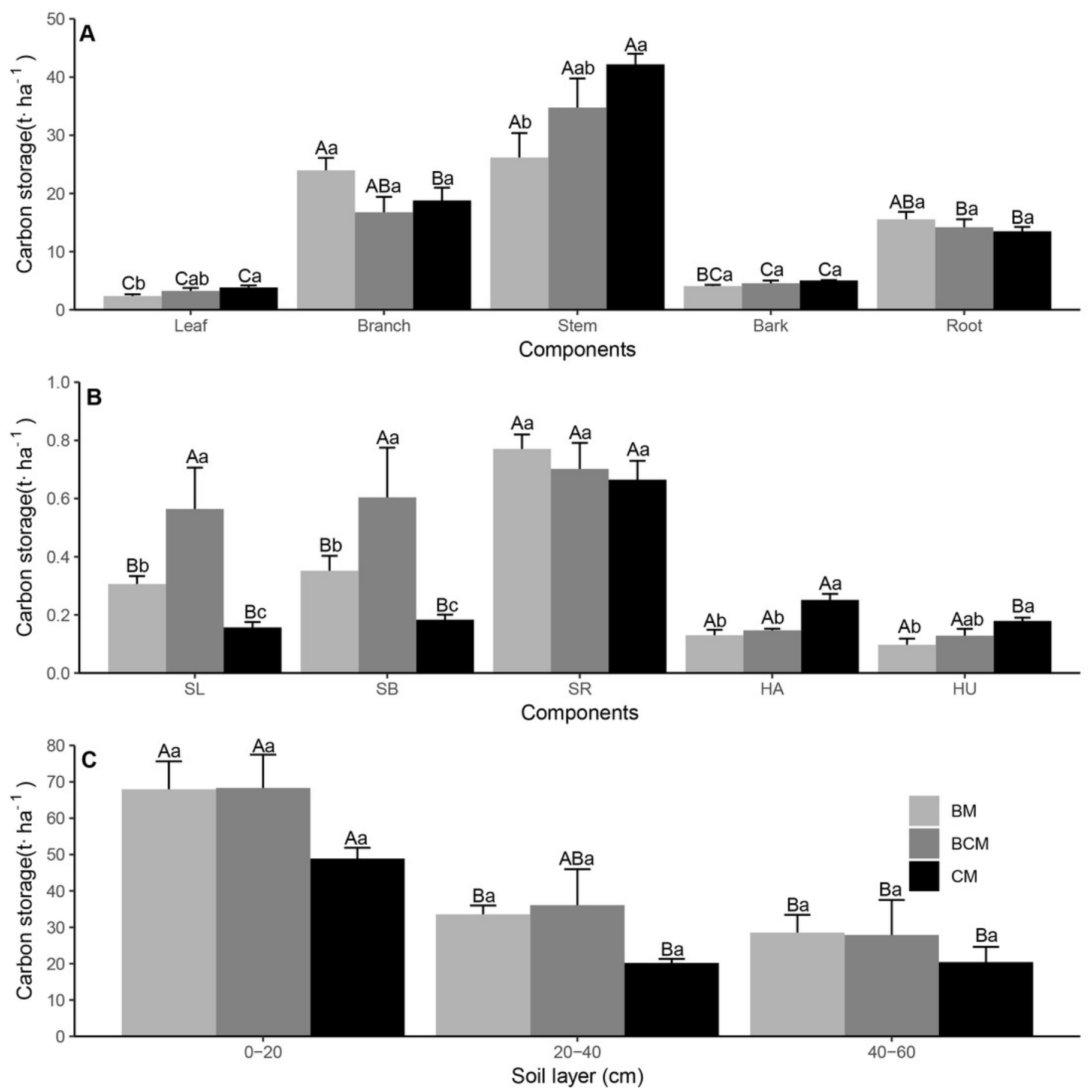


\section{Figure 6}

Nitrogen storage of trees (A), understory plants (B) organs and soil layers (C) in three secondary mixed forests.

Different lowercase letters above the bars indicate significant differences among different forest types for the same organ or soil layer $(p<0.05)$, while different uppercase letters indicate significant differences among different organs or soil layers for the same forest type $(p<0.05)$. SL: shrub leaf, SB: shrub branch, SR: shrub root, HA: herb aboveground, HU: herb underground. BM: broadleaf mixed forests, BCM: broadleaf-conifer mixed forests, $\mathrm{CM}$ : coniferous mixed forests. 

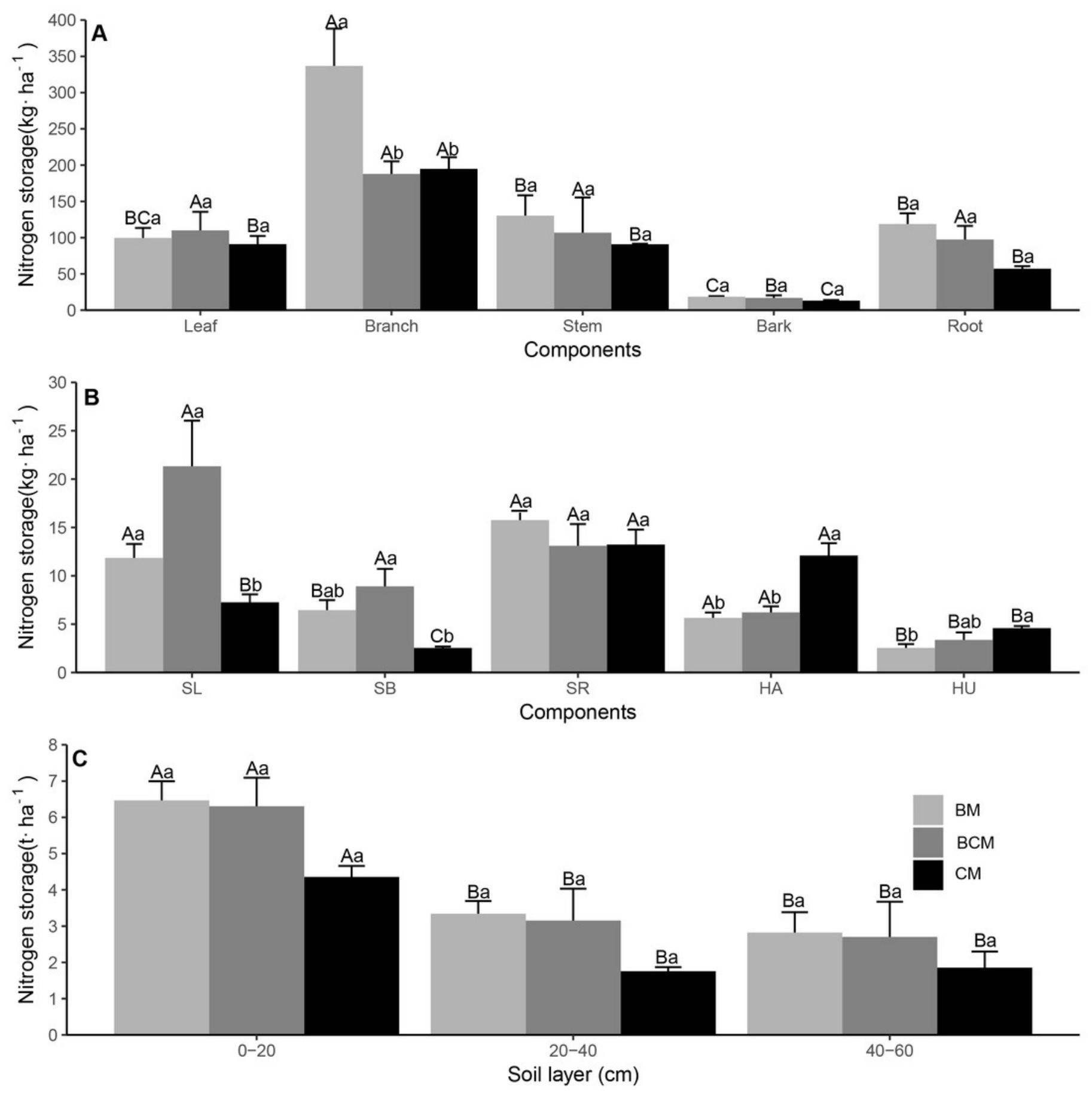


\section{Figure 7}

Phosphorus storage of trees (A), understory plants (B) organs and soil layers (C) in three secondary mixed forests.

Different lowercase letters above the bars indicate significant differences among different forest types for the same organ or soil layer $(p<0.05)$, while different uppercase letters indicate significant differences among different organs or soil layers for the same forest type $(p<0.05)$. SL: shrub leaf, SB: shrub branch, SR: shrub root, HA: herb aboveground, HU: herb underground. BM: broadleaf mixed forests, BCM: broadleaf-conifer mixed forests, $\mathrm{CM}$ : coniferous mixed forests. 

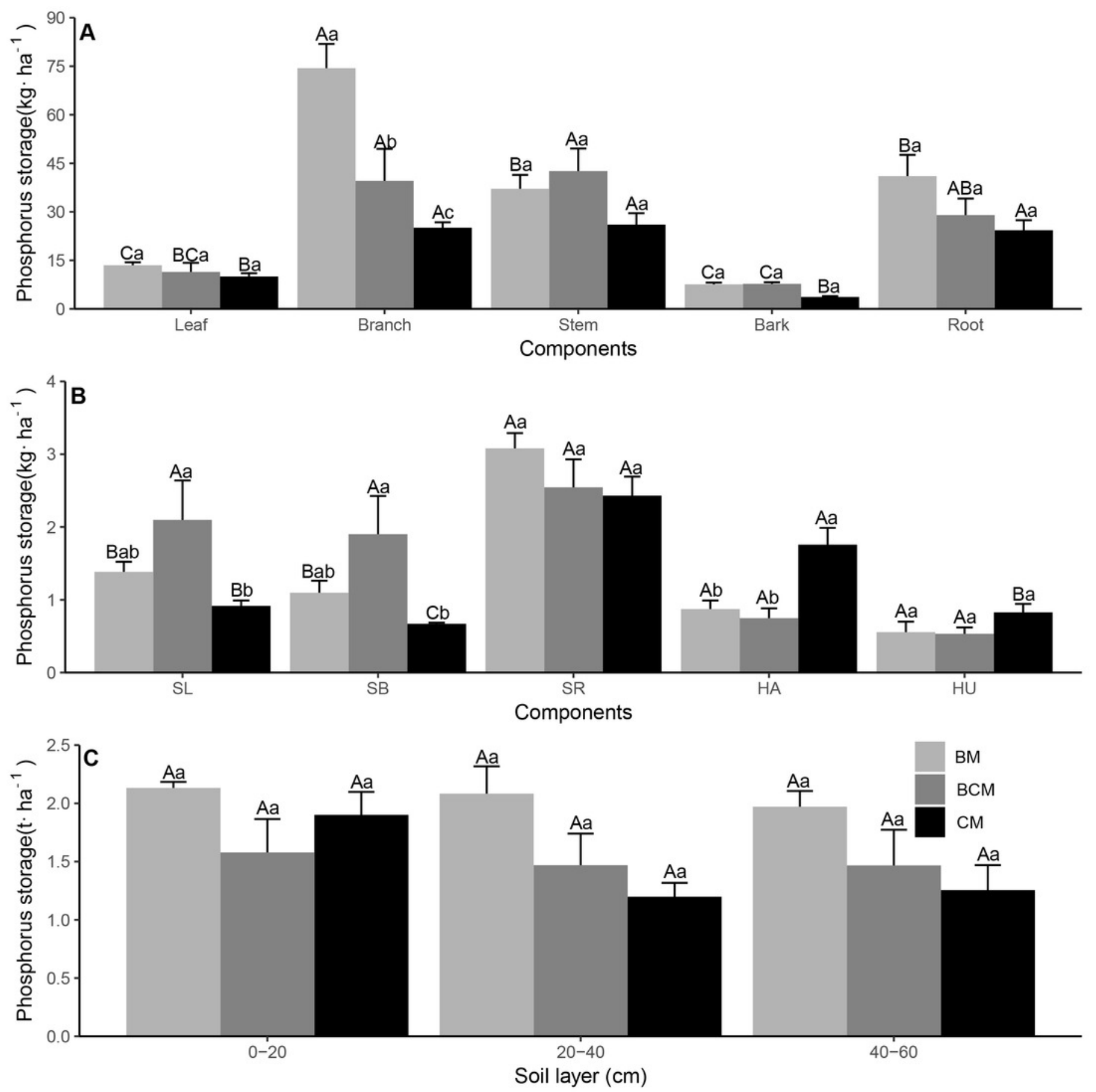


\section{Figure 8}

Pearson's correlation matrix between plant organs, litter and soil C, N, and P concentrations and stoichiometric ratios.

Note: $* p<0.05, * * p<0.01, * * * p<0.001$; purple indicates positive correlation and yellow indicates negative. L: leaf, B: branch, S: stem, TB: bark, R: root; G: litter, C: carbon concentration, $\mathrm{N}$ : nitrogen concentration, $\mathrm{P}$ : phosphorus concentration, $\mathrm{C}: \mathrm{N}$ : the ratio of carbon to nitrogen, N:P: the ratio of nitrogen to phosphorus, $C: P$ : the ratio of carbon to phosphorus, SOC: soil organic carbon, STN: soil total nitrogen, STP: soil total phosphorus, $\mathrm{SCN}$ : the ratio of soil carbon to soil nitrogen, SCP: the ratio of soil carbon to soil phosphorus, SNP: the ratio of soil nitrogen to soil phosphorus. 


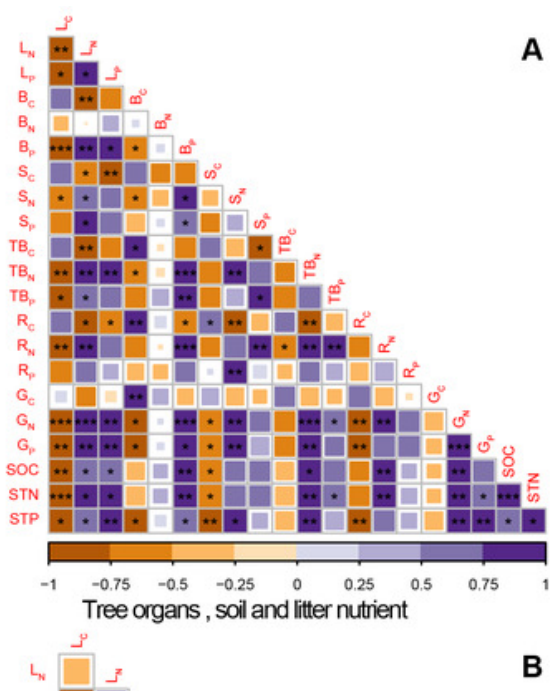

A

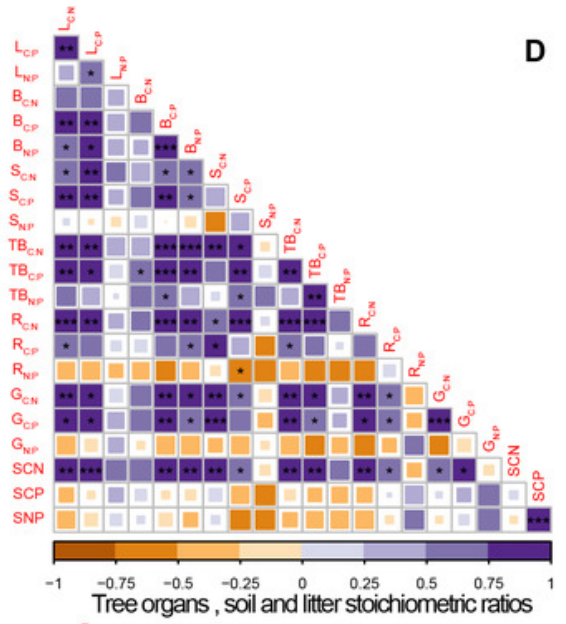

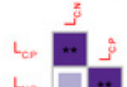

E
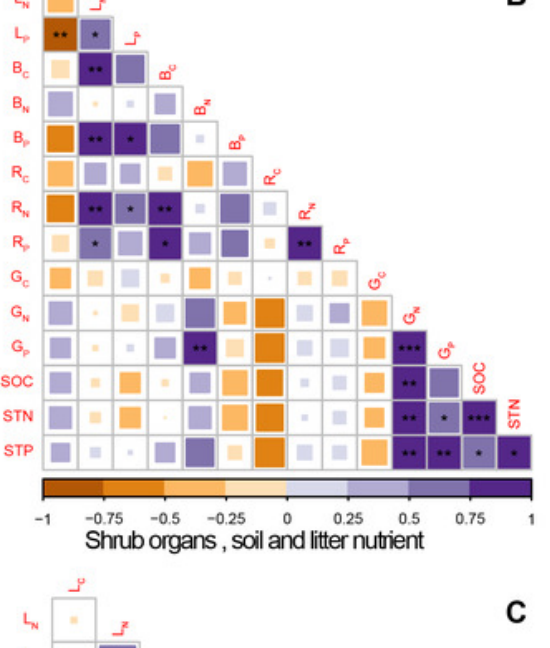

c

$L_{w e} \square \cdot 1$

$\mathrm{B}_{\mathrm{CN}} \square \square \infty^{2}$

$B_{C P} \square \square \square \square \infty_{\infty}^{\circ}$

$B_{w P} \cdot \square=\cdots \cdot \infty^{\frac{2}{2}}$

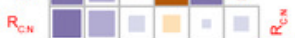

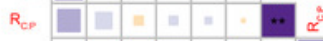

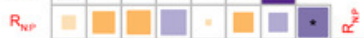

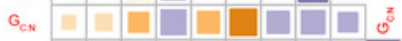

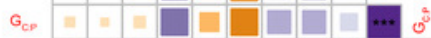

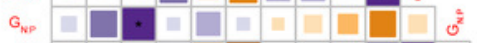

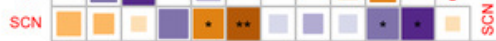

scp

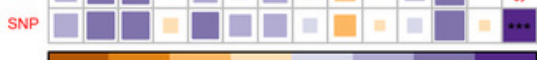

\begin{tabular}{llllllll}
\hline-1 & -0.75 & -0.5 & -0.25 & 0 & 0.25 & 0.5 & 0.75
\end{tabular}

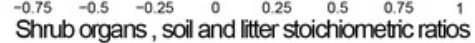

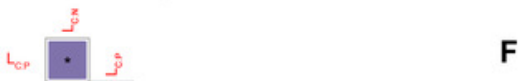

$L_{p} \square \square$ is

$R_{c} \square \square \square \alpha^{\circ}$

$R_{N} \square \square \square \cdot \alpha^{2}$

$R_{p} \square \square \square= \pm=\propto^{*}$

$G_{c} \quad \square= \pm=10=0$

$G_{N} \square=\square \square \square \cdot o^{2}$

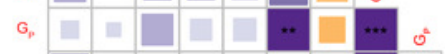

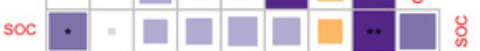

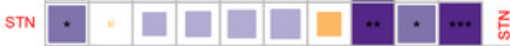

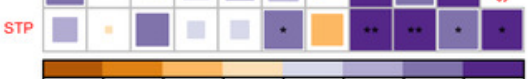

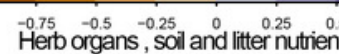

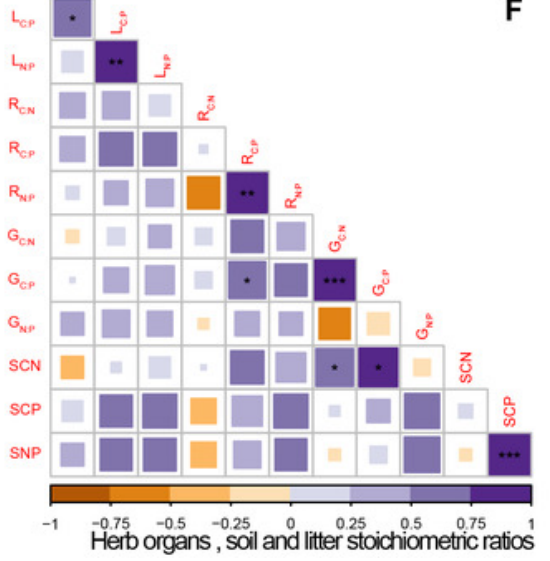




\section{Table $\mathbf{1}$ (on next page)}

Characteristics of sample plots in three secondary mixed forests.

BM: broadleaf mixed forests, BCM: broadleaf-conifer mixed forests, CM: coniferous mixed forests, DBH: diameter at breast height. 


\begin{tabular}{cccc}
\hline Forest types & BM & BCM & CM \\
\hline Altitude (m) & $1900-2150$ & $2000-2100$ & $1800-2000$ \\
Slope aspect & Northwest & Northeast & Northwest \\
Slope position & Central & Central & Below \\
Slope gradient $\left({ }^{\circ}\right)$ & $16-24$ & $11-20$ & $15-22$ \\
Fertigation & No & No & No \\
Trees & Betula albosinensis & Pinus armandii & Pinus armandii \\
& Quercus L. & Quercus L. & Picea asperata \\
& Acer davidii & & \\
Shrubs & Schisandra sphenanthera & Schisandra sphenanthera & Viburnum betulifolium \\
& Viburnum betulifolium & Smilax china & Lonicera fragrantissima \\
& Rubus mesogaeus & Viburnum betulifolium & Rubus mesogaeus \\
Herbaceous & Matteuccia intermedia & Tripterospermum chinense & Athyrium sinense \\
& Lysimachia christinae & Viola verecunda & Tripterospermum chinense \\
& Carex duriuscula & Carex duriuscula & Carex duriuscula \\
DBH (cm) & $17.24 \pm 1.76$ & $13.98 \pm 0.74$ & $19.06 \pm 0.52$ \\
Height (m) & $10.85 \pm 0.22$ & $11.84 \pm 0.56$ & $19.79 \pm 0.34$ \\
Density (n ha-1) & 933 \pm 246 & $1333 \pm 30$ & 783 \pm 88 \\
\hline
\end{tabular}




\section{Table 2 (on next page)}

Carbon storage of plant total biomass, litter total biomass, soil and net ecosystem.

Different letters indicate significant differences $(p<0.05)$ among forest types based on a one-way ANOVA followed by an LSD test. BM: broadleaf mixed forests, BCM: broadleaf-conifer mixed forests, CM: coniferous mixed forests. 


\begin{tabular}{|c|c|c|c|c|c|c|}
\hline \multirow{2}{*}{ Ecosystem pool } & \multicolumn{2}{|c|}{ BM } & \multicolumn{2}{|c|}{ ВCM } & \multicolumn{2}{|c|}{$\mathbf{C M}$} \\
\hline & C storage & percentage & C storage & percentage & C storage & percentage \\
\hline Tree $\left(\mathbf{t ~ h a} \mathbf{h}^{-1}\right)$ & $72.09 \pm 4.82$ & $35.09 \%$ & $73.49 \pm 9.71$ & $35.03 \%$ & $83.35 \pm 3.11$ & $47.13 \%$ \\
\hline Shrub $\left(t\right.$ ha $\left.^{-1}\right)$ & $1.43 \pm 0.06 \mathrm{ab}$ & $0.70 \%$ & $1.87 \pm 0.26 \mathrm{a}$ & $0.89 \%$ & $1.00 \pm 0.07 \mathrm{~b}$ & $0.57 \%$ \\
\hline Herb $\left(t \mathbf{h a}^{-1}\right)$ & $0.23 \pm 0.01 \mathrm{~b}$ & $0.11 \%$ & $0.27 \pm 0.01 \mathrm{~b}$ & $0.13 \%$ & $0.43 \pm 0.03 \mathrm{a}$ & $0.24 \%$ \\
\hline G-litter (t ha $\left.\mathbf{~}^{-1}\right)$ & $1.63 \pm 0.16 \mathrm{~b}$ & $0.80 \%$ & $1.82 \pm 0.10 \mathrm{~b}$ & $0.87 \%$ & $2.53 \pm 0.16 \mathrm{a}$ & $1.43 \%$ \\
\hline Soil $\left(t^{h a^{-1}}\right)$ & $130.05 \pm 13$ & $63.30 \%$ & $132.30 \pm 25$ & $63.08 \%$ & $89.54 \pm 4.01$ & $50.63 \%$ \\
\hline Net ecosystem ( $\left(\mathrm{ha}^{-1}\right)$ & $205.43 \pm 10$ & $100 \%$ & $209.75 \pm 35$ & $100 \%$ & $176.86 \pm 7.14$ & $100 \%$ \\
\hline
\end{tabular}

1 


\section{Table 3 (on next page)}

Nitrogen storage of plant total biomass, litter total biomass, soil and net ecosystem.

Different letters indicate significant differences $(p<0.05)$ among forest types based on a one-way ANOVA followed by an LSD test. BM: broadleaf mixed forests, BCM: broadleaf-conifer mixed forests, CM: coniferous mixed forests. 


\begin{tabular}{|c|c|c|c|c|c|c|}
\hline \multirow{2}{*}{ Ecosystem pool } & \multicolumn{2}{|c|}{ BM } & \multicolumn{2}{|c|}{ BCM } & \multicolumn{2}{|c|}{ CM } \\
\hline & N storage & percentage & N storage & percentage & N storage & percentage \\
\hline 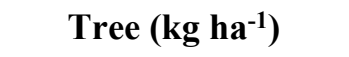 & $704.16 \pm 41$ & $5.24 \%$ & $518.96 \pm 112$ & $4.05 \%$ & $446.93 \pm 24$ & $5.24 \%$ \\
\hline Shrub $\left(\mathrm{kg} \mathrm{ha}^{-1}\right)$ & $34.06 \pm 0.70 \mathrm{a}$ & $0.25 \%$ & $43.33 \pm 6.7 \mathrm{a}$ & $0.34 \%$ & $23.03 \pm 1.05 \mathrm{~b}$ & $0.27 \%$ \\
\hline Herb $\left(\mathrm{kg} \mathrm{ha}^{-1}\right)$ & $8.20 \pm 0.16 b$ & $0.06 \%$ & $9.59 \pm 0.77 \mathrm{~b}$ & $0.07 \%$ & $16.68 \pm 1.5 \mathrm{a}$ & $0.20 \%$ \\
\hline G-litter $\left(\mathrm{kg} \mathrm{ha}^{-1}\right)$ & $70.35 \pm 5.07$ & $0.52 \%$ & $66.42 \pm 2.89$ & $0.52 \%$ & $77.27 \pm 4.51$ & $0.91 \%$ \\
\hline Soil $\left(t_{\text {ha-1 }}\right)$ & $12.63 \pm 1.33$ & $93.93 \%$ & $12.16 \pm 2.39$ & $95.02 \%$ & $7.97 \pm 0.29$ & $93.43 \%$ \\
\hline Net ecosystem (t ha $\left.{ }^{-1}\right)$ & $13.45 \pm 1.32$ & $100 \%$ & $12.80 \pm 2.5$ & $100 \%$ & $8.53 \pm 0.32$ & $100 \%$ \\
\hline
\end{tabular}
1 


\section{Table 4(on next page)}

Phosphorus storage of plant total biomass, litter total biomass, soil and net ecosystem.

Different letters indicate significant differences $(p<0.05)$ among forest types based on a one-way ANOVA followed by an LSD test. BM: broadleaf mixed forests, BCM: broadleaf-conifer mixed forests, CM: coniferous mixed forests. 


\begin{tabular}{|c|c|c|c|c|c|c|}
\hline \multirow{2}{*}{ Ecosystem pool } & \multicolumn{2}{|c|}{ BM } & \multicolumn{2}{|c|}{ BCM } & \multicolumn{2}{|c|}{ CM } \\
\hline & P storage & percentage & P storage & percentage & P storage & percentage \\
\hline Tree $\left(\mathrm{kg} \mathrm{ha}^{-1}\right)$ & $173.67 \pm 13 \mathrm{a}$ & $2.72 \%$ & $130.27 \pm 23 \mathrm{ab}$ & $2.8 \%$ & $89.13 \pm 3.9 b$ & $2.00 \%$ \\
\hline Shrub $\left(k_{g ~ h a}{ }^{-1}\right)$ & $5.56 \pm 0.19 \mathrm{ab}$ & $0.09 \%$ & $6.54 \pm 1.04 \mathrm{a}$ & $0.14 \%$ & $4.01 \pm 0.2 b$ & $0.09 \%$ \\
\hline Herb $\left(k g ~ h a^{-1}\right)$ & $1.43 \pm 0.04 \mathrm{~b}$ & $0.02 \%$ & $1.28 \pm 0.07 \mathrm{~b}$ & $0.03 \%$ & $2.58 \pm 0.32 \mathrm{a}$ & $0.06 \%$ \\
\hline G-litter (kg ha-1) & $6.86 \pm 0.53 \mathrm{ab}$ & $0.11 \%$ & $6.04 \pm 0.07 \mathrm{~b}$ & $0.13 \%$ & $7.77 \pm 0.36 \mathrm{a}$ & $0.17 \%$ \\
\hline Soil $\left(t\right.$ ha $\left.^{-1}\right)$ & $6.19 \pm 0.39$ & $97.06 \%$ & $4.51 \pm 0.8$ & $96.9 \%$ & $4.36 \pm 0.35$ & $97.76 \%$ \\
\hline Net ecosystem $\left(\mathrm{t} \mathrm{ha}^{-1}\right)$ & $6.37 \pm 0.39$ & $100 \%$ & $4.66 \pm 0.84$ & $100 \%$ & $4.46 \pm 0.34$ & $100 \%$ \\
\hline
\end{tabular}
1 